
\title{
$\begin{array}{ll}\text { Research Square } & \begin{array}{l}\text { Preprints are preliminary reports that have not undergone peer review. } \\ \text { They should not be considered conclusive, used to inform clinical practice, } \\ \text { or referenced by the media as validated information. }\end{array}\end{array}$
}

\section{A rapid review of the impact of COVID-19 on the mental health of healthcare workers: implications for supporting psychological well- being}

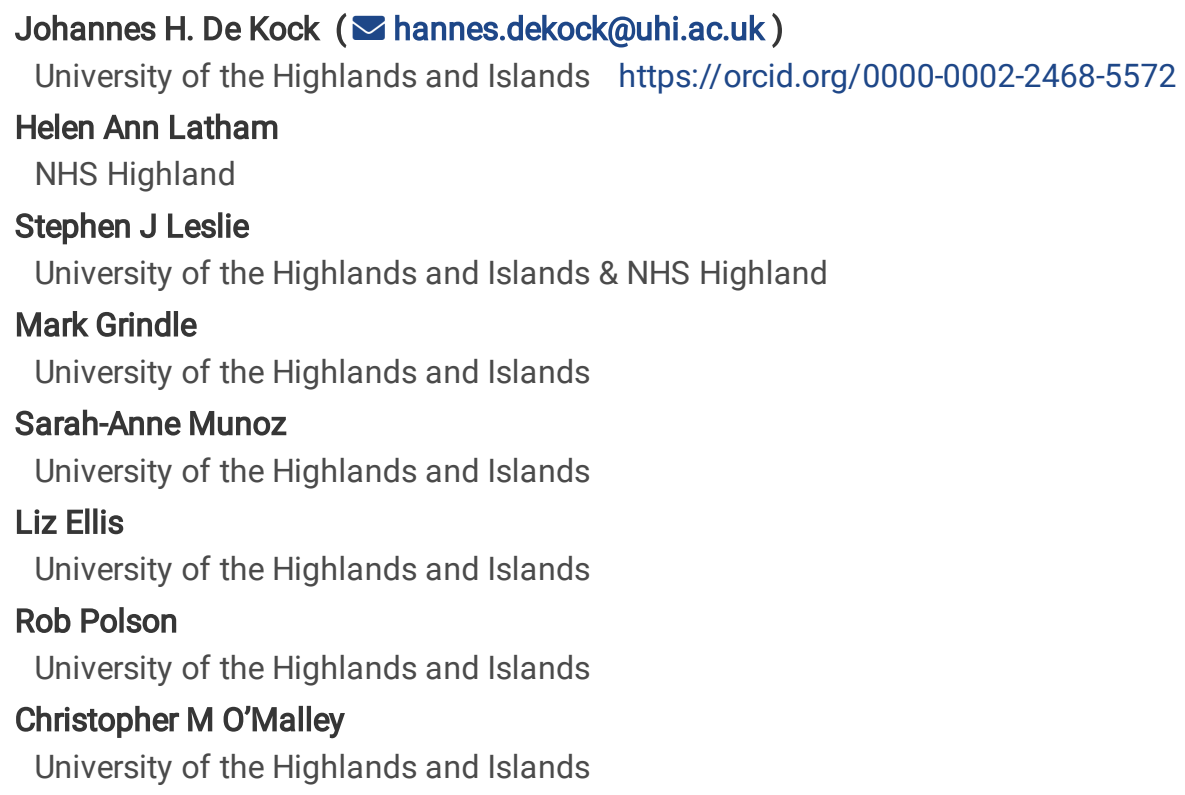

\section{Systematic Review}

Keywords: COVID-19, mental health, psychology, intervention, review, frontline, staff, workers, healthcare, social care

Posted Date: October 9th, 2020

DOI: https://doi.org/10.21203/rs.3.rs-62472/v2

License: () (1) This work is licensed under a Creative Commons Attribution 4.0 International License. Read Full License

Version of Record: A version of this preprint was published at BMC Public Health on August 24th, 2020. See the published version at https://doi.org/10.1186/s12889-020-10070-3. 


\section{Abstract}

Background

Health and social care workers (HSCWs) have carried a heavy burden during the COVID-19 crisis and, in the challenge to control the virus, have directly faced its consequences. Supporting their psychological wellbeing continues, therefore, to be a priority. This rapid review was carried out to establish whether there are any identifiable risk factors for adverse mental health outcomes amongst HSCWs during the COVID-19 crisis.

Methods

We undertook a rapid review of the literature following guidelines by the WHO and the COVID-19 Cochrane Collaboration's recommendations. We searched across 14 databases, executing the search at two different time points. We included published observational and experimental studies that reported the psychological effects on health and care workers during the COVID-19 pandemic.

Results

The 24 studies included in this review reported data predominantly from China (18 out of 24 included studies) and most sampled urban hospital staff. Our study indicates that COVID-19 has a considerable impact on the psychological wellbeing of front-line hospital staff. Results suggest that nurses may be at higher risk of adverse mental health outcomes during this pandemic, but no studies compare this group with the primary care workforce. Furthermore, no studies investigated the psychological impact of the COVID-19 pandemic on social care staff. Other risk factors identified were underlying organic illness, gender (female), concern about family, fear of infection, lack of personal protective equipment (PPE) and close contact with COVID-19. Systemic support, adequate knowledge and resilience were identified as factors protecting against adverse mental health outcomes.

\section{Conclusions}

The evidence to date suggests that female nurses with close contact with COVID-19 patients may have the most to gain from efforts aimed at supporting psychological well-being. However, inconsistencies in findings and a lack of data collected outside of hospital settings, suggest that we should not exclude any groups when addressing psychological wellbeing in health and social care workers. Whilst psychological interventions aimed at enhancing resilience in the individual may be of benefit, it is evident that to build a resilient workforce, occupational and environmental factors must be addressed. Further research including social care workers and analysis of wider societal structural factors is recommended.

\section{Background}

Health and social care workers (HSCWs) continue to play a vital role in our response to the COVID-19 pandemic. It is known that HSCWs exhibit high rates of pre-existing mental health $(\mathrm{MH})$ disorders (1-3) which can negatively impact on the quality of patient care.(4)

Studies from previous infectious outbreaks $(5,6)$ suggest that this group may be at risk of experiencing worsening $\mathrm{MH}$ during an outbreak. Current evidence examining the psychological impact on similar groups(7-9), suggest that this group may be at risk of experiencing poor $\mathrm{MH}$ as a direct result of the COVID-19 pandemic. Compounding the concerns about these data are that HSCWs will be likely to not only be at a higher risk for experiencing $\mathrm{MH}$ problems during the pandemic, but also in its aftermath.(5)

There are some specific features of the COVID-19 pandemic that may specifically heighten its potential to impact on the MH of HSCWs.

Firstly, the scale of the pandemic in terms of cases and the number of countries affected has left all with an impression that 'no-one is safe'. Media reporting of the pandemic has repeatedly focused on the number of deaths in HSCWs and the spread of the disease within health and social care facilities which is likely to have amplified the negative effects on the MH of HSCWs.

Secondly, usual practice has been significantly disrupted and many staff have been asked to work outside of their usual workplace and have been redeployed to higher risk front line jobs.

Finally, the intense focus on personal protective equipment (PPE) is likely to have specifically heightened the impact of COVID-19 on the $\mathrm{MH}$ of HSCWs due to the uncertainty surrounding the quantity and quality of equipment, the frequently changing guidance on what PPE 
is appropriate in specific clinical situations and the uncertainty regarding the absolute risk of transmission posed. While other workers will have been impacted by COVID-19, it is highly likely that the above factors will have disproportionately affected the MH of HSCWs(9, 10). Indeed a British Medical Association survey on the $14^{\text {th }}$ May 2020 during the pandemic showed that $45 \%$ of UK doctors are suffering from depression, anxiety, stress, burnout or other mental health conditions relating to, or made worse by, the COVID-19 crisis. (11)

Although evidence based psychological interventions are available for this population(12), there is a paucity of evidence about interventions for the $\mathrm{MH}$ of HSCWs during pandemics. Recent calls to action mandated the need to provide high quality data on the psychological impacts of the COVID-19 pandemic. $(13,14)$ This pandemic has rapidly changed the functioning of society at many levels which suggests that these data are not only needed swiftly, but also with caution and scientific rigour. $(13,14)$

These data are needed in order to equip HSCWs to do their job effectively - high levels of stress and anxiety have been shown to decrease staff morale, increase absenteeism, lower levels of work satisfaction and quality of care. $(6,15)$ It is therefore a priority to understand the psychological needs of our HSCWs in order to provide them with the appropriate tools to mitigate the negative effects of dealing with the COVID-19 pandemic.

While HSCWs have been identified as vulnerable to the negative psychological impact from the current pandemic, they do not form a homogeneous population. It may therefore be appropriate to identify particularly vulnerable groups within the larger population of HSCWs and target psychological support to them. This review seeks to understand whether any group of HSCWs could be confidently excluded from psychological support interventions because they are deemed to be at a low risk. Holmes et al(14) have warned that a one-size-fits-all approach to supporting HSCWs might not be effective. This, together with the lack of evidence around tailoring psychological interventions during pandemics(1), highlights the importance of identifying vulnerable groups, to ensure appropriately personalised interventions are made available.

The nature of the COVID-19 pandemic has brought lockdown and social distancing to many areas and countries around the world. The findings from the review have relevance for those looking to support HSCWs' psychological wellbeing during the COVID-19 pandemic.

\section{Aim of the Review}

The aim of this review is to identify the psychological impact of the COVID-19 pandemic on the health and social care professions, more specifically to identify which sub-groups are most vulnerable to psychological distress and to identify the risk and protective factors associated with this population's mental health.

Whilst previous reviews synthesised the psychological impact of earlier viral outbreaks together with that of COVID-19, it cannot be assumed that findings will remain similar and applicable to, for instance, digital health interventions -due to the global rapid uptake of digital technologies over the last decade. This review, looking exclusively at the psychological impact of the COVID-19 pandemic on HSCWs will therefore contribute to informing where mental health interventions, together with organisational and systemic efforts to support this population's mental health could be focussed in an effort to support psychological well-being. (14) Rapid but robust gathering of evidence to inform health decision-makers is vital and in circumstances such as these, the WHO recommends rapid reviews.

\section{Methods}

\section{Search strategy}

Planning, conducting and reporting of this study was based on the guidelines for rapid reviews(17), set by the WHO(16) and the recent COVID-19 Cochrane Collaboration's recommendations.(18)

\section{Data Sources and Searches}

Two authors (CoM \& RP) searched across a broad range of databases to capture research from potentially relevant fields, including health, mental health and health management. Within the OVID platform of databases Medline, EMBase, HMIC and PsychInfo were searched. Within the EbscoHost platform of databases, CINAHL, Medline, APA PsychInfo, Business Source Elite, Health Source and 
Academic Search Complete were searched. Beyond the OVID and EbscoHost platforms, SCOPUS, the King's Fund Library, Social Care Online, PROSPERO and Google Advanced were also searched, making 16 databases searched (14 unique databases and two having been searched twice on separate platforms).

Owing to the rapidly changing landscape of the COVID-19 pandemic, and in an effort to include as many eligible papers as possible, the search strategy was executed on 23 April 2020 and again two weeks later on 6 May 2020 using a combination of subject headings and keyword searching (see Appendix). The bibliographical database was created with EndNote $X 7^{\mathrm{Tm}}$.

\section{Search criteria}

The design of the search criteria was intended to draw together research both for this rapid review, and to contribute to the design of a digital mental health intervention to enhance the psychological well-being of HSCWs. The design of the search criteria is discussed in further detail in the Appendix.

\section{Types of participants}

\section{Participants were restricted to HSCWs during the COVID-19 pandemic.}

\section{Types of studies included}

Published observational and experimental studies that reported the psychological effects on HSCWs during the COVID-19 pandemic were included. The study designs included quantitative and qualitative primary studies. Studies relating to previous pandemics and epidemics (such as SARS, MERS, H1N1, H5N1, Zika, Ebola, West Nile Fever) were excluded as these results have been reported elsewhere. (7) Reviews, theses, position papers, protocol papers, and studies published in languages other than English were excluded.

\section{Screening and selection of studies}

Searches were screened according to the selection criteria by JDK. The full text of potentially relevant papers was retrieved for closer examination. The reviewer erred on the side of inclusion where there was any doubt, to ensure no potentially relevant papers were missed. The inclusion criteria were then applied against full text versions of the papers (where available) independently by JDK and HL. Disagreements regarding eligibility of studies were resolved by discussion and consensus. Where the two reviewers were still uncertain about inclusion, the other reviewers (RP, CoM) were asked to provide input to reach consensus.

\section{Data Extraction and Quality Assessment}

Relevant data were extracted into structured tables including country, setting, population, study design, number of participants, mental health conditions and their measurement tools and main study results. Where available, we extracted risk factors and protective factors. HL, LE and JDK extracted all the data while JDK checked for accuracy and completeness.

Table 2 presents an overview of the validated tools used per study type to assess study quality and risk of bias. JDK and HL assessed the quality of cross-sectional studies with the Joanna Briggs Institute tool (19) and JDK assessed their risk of bias using the Evidence Partners (20) appraisal tool. JDK assessed the risk of bias for the longitudinal study with the Critical Appraisal Skills Programme (CASP) appraisal tool(21) and the uncontrolled before-after study with the ROBINS - I. (22) SAM utilised Joanna Briggs Institute tool to assess the qualitative studies (23) and the Mixed methods appraisal tool (MMAT)(24) to assess mixed methods studies.

\section{Data Synthesis and Analysis}

Current best practice guided the tabulated and narrative synthesis of the results. $(25,26)$ The studies' outcomes were categorised according to the psychological impact of COVID-19 on HSCWs of: 
a. general psychological impacts

b. the risk factors associated with adverse mental health outcomes

c. the protective factors against adverse mental health outcomes

Previous studies' logical syntheses(6) were adapted by organising the risk and protective factors into psychosocial, occupational, sociodemographic and environmental categories. The GRADE method from the Cochrane Collaboration(27) was used to assess the quality of evidence of outcomes included in this rapid review. Varied study quality, together with study type and outcome heterogeneity precluded performing a meta-analysis.

\section{Patient and public involvement}

Some members of the author team are frontline healthcare staff during the COVID-19 pandemic and contributed to the design of the review.

\section{Results \\ Search Results}

The 677 records of interest were found from the two searches (429 in search 1 and 529 in search 2). After 148 duplicates were removed, 529 records were screened. Of these, 82 full texts of potentially relevant studies were assessed for eligibility (see Figure 1). Twenty-four published studies met the inclusion criteria for the rapid review.

\section{Study Characteristics}

The 24 studies included in this review consisted of 18 cross-sectional, 2 mixed methods, 2 qualitative, 1 longitudinal and 1 uncontrolled before-after study. The total number of participants in these studies was 13,731 . In the cross-sectional studies, participant numbers ranged between 59 and 2,299. Participant numbers in the two mixed method studies were 37 and 222 respectively, whilst the qualitative studies included 10 and 20 participants, respectively. The longitudinal study included 120 participants and the uncontrolled before-after study,27 participants. See Table 1 for sampling methods within the included papers. The majority of papers utilised non-probability sampling methods limiting generalisability of findings. One exception was Lai et al, who used region stratified 2-stage cluster sampling.

Eighteen of the studies were from China, of which 8 were based in Wuhan, where the COVID-19 outbreak began. The rest were from America (1), Israel (1), UK (1), Singapore (1), Pakistan (1), multicentre - Singapore \& India (1), Global (1). Several validated measures were used to assess anxiety, depression, insomnia, stress and burnout. Table 1 provides an overview of the included studies.

\section{Risk of bias assessment}

The quality of the cross-sectional studies was fair, with 16 studies scoring 6 or higher on the JBI appraisal tool and eleven scoring 7 or higher (a score of 7 and above is an indicator of study quality). The majority of the studies indicated a low risk of bias when assessed with the Evidence Partners' appraisal tool. The uncontrolled before-after study indicated a high risk of bias. The qualitative studies indicated a good level of quality (JBI scores of 9 \& 10 respectively) while mixed methods studies showed varied quality. In the cross sectional studies, the most common problem affecting study quality was failure to deal with confounding factors. Failure to locate the researcher culturally or theoretically affected the qualitative papers, whilst the two mixed methods papers' study quality was affected by lack of explicitly articulated research questions. A summary of the risk of bias and quality assessments are provided in Table 2.

\section{Psychological Toll on Healthcare Workers}

Of the 24 studies included, 22 directly assessed the psychological toll on healthcare workers and all found levels of anxiety, depression, insomnia, distress or Obsessive Compulsive Disorder (OCD) symptoms.(28-49) 
Psychological symptoms were assessed using various validated measures as outlined in Table 3 - the summary of included studies. The most common outcomes assessed were sleep, anxiety and depression. The prevalence of depressive symptoms varied greatly, ranging between $8.9 \%$ (42) to $50.4 \%$.(36) These findings suggest marked differences in the prevalence of depressive symptoms across the studies.. The prevalence of anxiety in cross-sectional studies ranged between $14.5 \%$ (42) to $44.6 \%$.(36) Sleep was also assessed in several studies. Lai et al (36) found the prevalence of sleep disturbances to be $34 \%$, whilst another, nationwide survey in China found that HCWs had significantly worse sleep than the general population.(34)

\section{Risk factors associated with adverse mental health outcomes}

Table 3 provides the GRADE evidence profile of the certainty of evidence for the risk factors associated with adverse MH outcomes during the COVID-19 pandemic identified through the review. These risk factors can be grouped into the three thematic areas of i) occupational, ii) psychosocial, iii) environmental.

\section{Occupational factors}

Medical HCWs: Two studies showed that medical HCWs (nurses and doctors) had significantly higher levels of MH risk in comparison to non-medical HCWs. $(38,49)$ Zhang et al $(49)$ found that medical HCWs had significantly higher levels of insomnia, anxiety, depression, somatization and OCD symptoms in comparison to non-medical HCWs. This was also reflected in a large study in Fujian province, China, in which medical staff had significantly higher anxiety than admin staff.(38) In contrast, Tan et al (42) found that in a population of $470 \mathrm{HCWs}$ in Singapore, the prevalence of anxiety was significantly higher among non-medical HCWs than medical.

Healthcare groups: In three studies nurses were found to be at risk of worse $\mathrm{MH}$ outcomes than doctors $(29,31,36)$. One large study in China found nurses were at significant risk of more severe depression and anxiety than doctors.(36) Another found that nurses had significantly higher financial concerns than doctors and felt significantly more anxious on the ward when compared with other groups. There was no significant difference between professionals regarding stopping work or work overload.(29) A mixed method paper also showed that nurses had a higher rate of depressive symptoms than doctors. Whilst this was a small sample size, it echoes the findings from larger studies.(31)

With regard to other HCWs, there were two studies which assessed dentists and other dental workers and found them to be at risk of anxiety and elevated distress. Neither study found any difference based on gender or educational level. $(28,40)$ There were no studies comparing dental workers to other HCWs. We did not find any studies that focussed on the primary care workforce or that assessed social care workers.

With regard to seniority, one paper found that having an intermediate technical title was associated with more severe MH symptoms.(36)

Frontline staff/Direct contact with COVID-19: Four high-quality studies found being in a 'frontline' position or having direct contact with COVID-19 patients was associated with higher levels of psychological distress. $(35,36,38,44)$

Increased direct exposure to COVID-19 patients increased the mental health risks in health care workers in one study in Wuhan.(35) This finding is backed by Lai et al(36), who found that being a frontline worker was independently associated with more severe depression, anxiety and insomnia scores. In addition, a cross sectional survey of staff in a paediatric centre found that contact with COVID-19 patients was independently associated with increased risk of sleep disturbance.(44) Lu et al (38) found that medical HCWs in direct contact with COVID-19 patients had almost twice the risk of anxiety and depression than non-medical staff with low risk of contact with COVID-19.

There were conflicting results found in two studies. A study in a cancer hospital in Wuhan found burnout frequency to be lower in frontline staff.(45) The authors identified confounding factors which may have led to this result, but it is of interest as it is one of the only studies that assessed HCWs outside of the acute general medicine setting. Li et al (50), also found that frontline nurses had significantly lower levels of vicarious trauma scores than non-frontline workers and the general population.

Personal protective equipment (PPE): PPE concerns were the most common theme brought up voluntarily in free-text feedback in a study by Chung \& Yeung (33), and a survey in Pakistan revealed that $80 \%$ of participants expected provision of PPE.(43) H.Cai et al (29) also found that PPE was protective when adequate, but a risk factor for stress when inadequate. This finding appears to be bolstered by a 
qualitative study of frontline nurses in Wuhan, which found that physical health and safety was one of their primary needs. This study also reported PPE as a protective factor (48).

Heavy Workload: Longer working time per week was found to be a risk factor in a study by Mo et al.(39) This, together with increased work intensity or patient load per hour, were themes in a mixed methods study of 37 staff of a clinic in Beijing (31) and a qualitative study of nurses in China (41), also suggesting heavy workload as a risk factor.

Psychosocial Factors

Fear of infection: A fear of infection was a highlighted in a qualitative study by Cao et. al., (2020)(31), and brought up as a theme in freetext feedback in a cross sectional survey by Chung \& Yeung.(33) Ahmed et al(28) found that $87 \%$ of dentists surveyed described a fear of being infected with COVID-19 from either a patient or a co-worker.

Concern about family: This was brought up as one of the main stress factors in a study by H.Cai et al(29), particularly amongst staff in the 31-40 year age-group. Knowing that their family was safe was also the greatest stress reliever(29), whilst fear of infecting family was identified in $79.7 \%$ of 222 participants in a study in Pakistan.(43) It was also a theme highlighted in the qualitative data.(31, 41)

Sociodemographic Factors

Younger Age: One Chinese web-based survey which included the general population and HCWs, showed that younger people had significantly higher anxiety and depression scores, but no difference in sleep quality. Conversely, the same study found that HCWs were significantly more likely to have poor sleep quality, but found no difference in anxiety or depressive symptoms based on occupation. The study did not examine the effect of age group on HCWs.(34)

H. Cai et al(29) suggested that age was more complex. They found that all age groups had concerns, but that the focus of their anxieties were different (for example: older staff were more likely to be anxious due to exhaustion from long hours and lack of PPE while younger staff were more likely to worry about their families).

Gender: Women were found to be at higher risk for depression, anxiety and insomnia by Lai et al.(36) This was also found to be an independent risk factor for anxiety in another large nationwide Chinese study.(49) However, a global survey of dentists found no differences based on gender.(28)

Underlying illness: We found two studies which identified that having an underlying organic illness as an independent risk factor for poor psychological outcomes. A study of dentists in Israel found an increase in psychological distress in those with background illnesses as well as an increased fear of contracting COVID-19 and higher subjective overload.(40) In medical HCWs in China, organic illness was found to be an independent risk factor for insomnia, anxiety, OCD, somatising symptoms and depression in medical HCWs.(49)

Being an only child: This was independently associated with sleep disturbance in paediatric HCWs in Wuhan.(44) Being an only child was also found to be significantly associated with stress by Mo et al.(39)

There was also a significant association between physical symptoms and poor psychological outcomes in a large multicentre study based in India and Singapore. It is unclear if this represented somatization or organic illness and the authors suggest the relationship between physical symptoms and psychological aspects was bi-directional.(32)

Environmental Factors

Point in pandemic curve: One longitudinal study carried out in China in a surgical department, found that anxiety and depression scores during the 'outbreak' period were significantly higher when compared to a similar group assessed after the outbreak period.(47) This was a small sample of 120 and only assessed surgical staff, but this longitudinal data was supported by a qualitative study in China which suggested that anxiety peaks at the start of the outbreak and reduces with time.(41)

Geography: Living in a rural area was only assessed by one study which showed that it was an independent risk factor for insomnia and anxiety in medical HCWs.(49) This may reflect a need to further investigate the effect of rurality on psychological wellbeing during this pandemic.

\section{Protective factors against adverse mental health outcomes}

Page $7 / 28$ 
The review identified protective factors against adverse mental health outcomes during COVID-19. Table 4 provides the GRADE evidence profile of the certainty of evidence for this. The protective factors can be grouped into the three thematic areas of: i) occupational, ii) psychosocial and iii) environmental.

\section{Occupational Factors}

Experience: W. Cai et al(30) found that previous experience in a public health emergency (PHE) was protective against adverse mental health outcomes. Staff that had no previous experience were also more likely to have low rates of resilience, and social support.

Training: A small cohort study of 27 surgeons, who were given pre and post training surveys, suggested that training alleviates psychological stress.(51) Good hospital guidance was identified to relieve stress in a study by H.Cai et al(29), and increasing selfknowledge was a coping strategy deployed by staff. Dissemination of knowledge was also mentioned in a qualitative study by Yin \& Zeng(48); participants described subjective stress reduction after their seniors explained relevant knowledge to them.

Adequate PPE: As mentioned above, PPE was found to be a protective factor when adequate and a risk factor for poor mental health outcomes when deemed to be inadequate. $(29,48)$

Psychosocial Factors

Resilience: One study assessed self-efficacy in dental staff and found that it was a protective factor.(40) Self-efficacy was also found to improve sleep quality by Xiao et al(46), whilst W.Cai et al(30) measured resilience using a validated measure and found it to be a protective factor against adverse $\mathrm{MH}$ outcomes.

Being in a committed relationship: This was found to be protective by Shacham et al.(40) This was not directly assessed in other studies.

Safety of family: This had the biggest impact in reducing stress in a cross-sectional study by H. Cai et al.(29) This was also not assessed in other studies.

Environmental Factors

Support: Support and recognition from the health care team, government and community was identified as a protective theme in several studies. Social support, measured using the Social Support Rate Scale (SSRS) was found to indirectly affect sleep by directly reducing anxiety and stress and increasing self-efficacy.(46)

Team support was identified as a protective factor in a qualitative study by Sun et al.(41) Good hospital guidance was also identified as a stress reliever by $\mathrm{H}$. Cai et al(29), who found that HCWs expected recognition from the hospital authorities. This was echoed in a qualitative study of nurses in Wuhan where the desire for community concern was a strong need and tightly linked to the need for PPE and knowledge:(48)

'To be honest, I was very apprehensive before coming to the infectious department as support staff, but on the first day here, the head nurse personally explained relevant knowledge such as disinfection and quarantine, and that helped me calm down a lot."

"I hope that our society and government pay more attention to lack of personal protective equipment'(48)

\section{Discussion}

As a communicable disease, and now a global public health emergency (PHE), COVID-19 places a unique challenge on our health and social care workforce that will disrupt not just their usual workplace duties but also their social context.(52) As we adjust to new ways of living and working, HSCWs are likely to continue to face challenges ahead. Our review confirms that the psychological impact of COVID-19 on health care workers is considerable, with significant levels of anxiety, depression, insomnia and distress. Studies revealed a prevalence of depressive symptoms between $8.9 \%-50.4 \%$ and anxiety rates between $14.5 \%-44.6 \% .(36,42)$ This is in keeping with other reviews and findings from previous viral outbreaks. $(7,8,53)$ The majority of studies published to date come from China, particularly Wuhan - the epicentre of COVID-19. There is minimal evidence published to date on the psychological impact on HCWs in Europe or the US, which have been highly impacted by the pandemic. The studies included in this review were predominantly concerned 
with hospital settings - we found no studies relating to social care staff or primary care staff. This is a concern, as we have increasing evidence that a large proportion of Western deaths are happening in the community and specifically in care homes.(54)

Our review aimed to identify whether there were any groups particularly vulnerable to poor mental health outcomes during COVID-19. We found some evidence that nurses may be at a higher risk than doctors. $(29,31,36)$ This is similar to findings which take into account previous viral outbreaks.(7) Confounding factors were not robustly addressed however, and there were no studies that compared nurses with the primary care workforce or social care workers. There was some evidence that clinical HCWs may be at higher risk of psychological distress than non-clinical $\operatorname{HCWs}(38,49)$, but this was not absolute. Tan et al(42) found a higher prevalence of anxiety among non-medical HCWs in Singapore. The prevalence of poor MH outcomes varied between countries. Chew et al(32) revealed that in data from India and Singapore, there was an overall lower prevalence of anxiety and depression than similar cross-sectional data from China.(32, 33, 36, 42) This suggests that different contexts and cultures may reveal different findings. It is possible that being at different points in their respective countries' outbreak curve may have played a part, as there was evidence that this may be influential. (47) Tan et al(42) postulated that the medical HCWs in Singapore had experienced a SARS outbreak in the past and thus were well prepared for COVID-19 both psychologically and in their infection control measures. What we can deduce is that context and cultural factors are likely to play a role, not just cadre or role of healthcare worker. It also highlights the importance of reviewing the evidence as more data emerges from other countries.

Several risk factors emerged, many in keeping with what has been found in other reviews. $(7,8)$ Those with the strongest evidence were inadequate $\operatorname{PPE}(29,33,43,48)$, fear of infection $(28,31,33)$ and heavy workload. $(31,39,41)$ Consistent with prior outbreak data $(7,53)$, there was also good evidence that close contact with COVID-19 cases was a predictor of higher levels of anxiety, depression and insomnia $(35,36,38,44)$, although two studies appeared to show conflicting results. $(45,50)$ Studies suggested that being younger in age $(29,34,37)$ or being female $(28,36,49)$ may be a risk factor, however this should be treated with caution. An alternative explanation for this study's findings may be greater risk of frontline exposure amongst women, who are predominantly employed in lower status roles within healthcare globally according to the WHO.(57) It is important to note that respondents to all studies, when disaggregated by gender, were predominantly female and this may have impacted findings. The consistently higher mortality rate and risk of severe COVID-19 disease amongst men would suggest that the full picture regarding gender and MH during this pandemic is incomplete.(55, 56) Although other risk factors were also identified, their certainty of evidence was deemed to be low.

The majority of cross-sectional studies focussed on measuring adverse MH outcomes which explains the lack of quantitative data on protective factors or coping mechanisms. Of the studies that did assess this, there were protective factors which were associated with adaptive psychological outcomes. Experience of prior infectious disease outbreaks and training were protective against poor mental health outcomes. $(29,30,48,51)$ Adequate PPE was a protective factor when adequate and a risk factor when inadequate. $(29,33,48)$ There was good evidence that resilience (measured by self-efficacy or resilience scales) was protective against poor mental health outcomes. $(30,40,46)$ This is of importance when assessing how to positively contribute to reducing the psychological burden on our health and social care staff. There was strong evidence that community support was a protective factor. $(29,41,46,48)$ Community support was important in a number of studies, referring to social support as well as recognition and support from the healthcare team, government and wider community. $(29,41,46,48,58)$ Other adaptive behaviours emerged from qualitative data, including gratitude and the ability to find purpose and growth from the situation.(41) These findings are in keeping with a recent study which identified key domains of risk for burnout in healthcare. They highlighted that being part of a supportive team community is a strong protective factor as are clear values and meaningful work.(59) They advise that organisational-level interventions creating a healthy workplace are the key to preventing burnout.(59) This is echoed in a recent systematic review and meta-analysis of the effectiveness of interventions designed to reduce symptoms and prevalence of $\mathrm{MH}$ disorders and suicidal behaviour among physicians. This review concluded that, whilst individually directed interventions are associated with some reduction in symptoms of common $\mathrm{MH}$ disorders, there needs to be increased focus on organisational-level interventions that improve the work environment.(2)

Whilst our findings showed evidence that occupational and environmental factors at the workplace level played a key role for $\mathrm{MH}$ outcomes, there was no mention of wider societal structural issues that have been emerging during this pandemic. Of particular importance is the evidence that black and ethnic minority people of all ages in the global north are at greater risk of contracting and dying from COVID-19.(60-62) A recent large study in the US found that non-white HCWs were at increased risk of contracting COVID-19 and were disproportionately affected by inadequate PPE and close exposure to COVID-19 patients.(3) This suggests wider structural factors are at play and need to be investigated. 
The paucity of empirical studies investigating the mental health of social care and primary care staff during the COVID-19 pandemic should also be rectified. With the majority of studies taking place in China, where ageing in place rather than residential care is the norm(63), it is unsurprising that none investigated care homes, where it is estimated around $40-50 \%$ of all deaths related to COVID- 19 occur in Europe and the US.(54) Moreover, there is evidence that front-line HCWs who work in nursing homes are among the highest at risk of contracting the virus.(3) With the majority of studies taking place in urban hospital settings, and particularly in Wuhan - the epicentre of the outbreak - the generalizability of findings to other settings may be limited, particularly as countries pass through different points in the outbreak curve. However, this review does highlight the considerable psychological impact that COVID-19 has played so far on health care workers and, therefore, adds to the recent calls to take notice of this important issue.(14) Yet the evidence also suggests that, although predictors for psychological distress exist, these are not absolute and context may play an important role on the manifestation of adverse $\mathrm{MH}$ outcomes.

\section{Strengths and limitations}

This rapid review has synthesized and discussed the current literature on the psychological impact of the COVID-19 pandemic on health and social care workers. A major limitation was that no empirical studies investigating this impact on social care workers could be found - limiting generalisability to the population reviewed. Recent evidence also suggests that having an ongoing connection to a paid job, may be protective against poor $\mathrm{MH}$ outcomes during the pandemic.(64) It would therefore be useful to compare $\mathrm{MH}$ outcomes amongst HCWs, or the general population, who were not actively employed during the pandemic. Unfortunately, none of the studies included this data. Furthermore, job retention schemes have varied widely between countries worldwide, thus limiting the generalisability of findings if this data had been available.(65)

However, to our knowledge, this is the first review investigating this population group in the context of COVID-19, without including prior viral outbreaks in its analysis and synthesis. We see this as a strength because this outbreak is different, and worth assessing in its own right. It has affected every country across the globe and disrupted everyday living in a way no other outbreak has in living memory (14). A major strength of our review is that it endeavoured towards greater inclusion, during the rapidly changing COVID-19 landscape, by completing two runs of the search strategy spaced two weeks apart. Whilst we adhered to high methodological standards by assessing study quality and risk of bias, together with using the GRADE approach to evaluate the certainty evidence and following best practice principles $(25,26)$ to present a narrative and tabulated synthesis, our review remains a rapid one with further clear limitations. The majority of the studies included in this review, for example, were from China and our selection criteria did not include studies from lowincome countries or studies in languages other than English - limiting the generalizability of our findings. Being a rapid review, the protocol was not registered on PROSPERO and only one reviewer was responsible for the initial screening of papers and for several of the quality assessments.

\section{Conclusions}

This rapid review confirms that front line HCWs are at risk of significant psychological distress as a direct result of the COVID-19 pandemic. Published studies suggest that symptoms of anxiety, depression, insomnia, distress and OCD are found within the healthcare workforce. However, most studies draw only from work in secondary care and none draw from the primary care or social care setting.

Published studies so far are predominantly from China (18 out of 24 included studies) and most of these have sampled hospital staff in Wuhan - the epicentre. Findings in this review suggest that the study of different contexts and cultures may reveal different findings and we recommend more research in primary care and social care settings and to monitor rapidly emerging evidence from across the world. This should include analysis of wider societal factors including gender, racial and socio-economic disparities that may influence mental health outcomes in HCWs.

Although risk factors did emerge that were in keeping with evidence from other infectious disease outbreaks, our findings were not absolute. This review suggests that nurses may be at higher risk of adverse $\mathrm{MH}$ outcomes during this pandemic, but there were no studies comparing them with social care workers or the primary care workforce. Other risk factors that recurred in the data were heavy workload, lack of PPE, close contact with COVID-19, being female and underlying organic illness. Inconsistencies in findings and lack of data on staff outside hospital settings, suggest that targeting a specific group within health and social care staff with psychological interventions may be misplaced - as both presence of psychological distress and risk factors are spread across the healthcare workforce, rather than associated with particular sub-groups. 
A recent call to action for mental health science during COVID-19 recommends research be undertaken to identify interventions that can be delivered under pandemic conditions to mitigate deteriorations in psychological well-being and support mental health. This call to action advised that personalised psychological approaches are likely to be a key. (14) Data from this review suggests that interventions which bolster psychological resilience may be of benefit because this was found to protect against adverse mental health outcomes. Due to the nature of the pandemic which prevents face-to-face interventions, this is likely to be digitally based. A recent systematic review, pre-dating COVID-19, suggested that individualised interventions can have modest effect on reducing adverse mental health outcomes amongst physicians.(2) However, our findings suggest that occupational and environmental factors in the workplace play a key role as risk factors and protective factors for mental health outcomes during this pandemic. Heavy workload, proximity to COVID-19 and inadequate PPE were risk factors for poor mental health, whereas good knowledge of COVID-19, a supportive work environment and adequate PPE were protective factors. It would appear from our findings that adequate PPE may be protective not just against infection, but also against adverse mental health outcomes. Individually targeted digital interventions are unlikely to address these factors.(2) We postulate that strengthening psychological resilience in a personalised approach may be effective in protecting our health and social care workers from adverse mental health outcomes but this must not defer responsibility from wider organisations and systems. We suggest that a holistic approach to HCWs psychological wellbeing is needed that includes personalised interventions alongside necessary structural changes to create a healthy, safe and supportive work environment. Further research including social care workers and analysis of wider societal structural factors is recommended.

\section{Abbreviations}

CD-RISC: Connor-Davidson Resilience Scale

CES-D: Centre for Epidemiologic Studies Depression Scale (CES-D)

COVID-19: Coronavirus disease 2019

DASS-21: Depression, Anxiety and Stress Scale

GAD-7: Generalised Anxiety Disorder Questionnaire

GRADE: The Grades of Recommendation, Assessment, Development and Evaluation Working Group

GSES: Generalised self-efficacy scale

HAM-A: Hamilton Anxiety Rating Scale

HAM-D: Hamilton Depression Rating Scale

HCWs: healthcare workers

HSCWs: health and social care workers

IES-R: Impact of Event Scale

ISI: Insomnia Severity Index

MBI: Maslach Burnout Inventory (MBI)

MH: mental health

PHE: Public Health Emergency

PHQ-4: Patient Health Questionnaire-4

PHQ-9: Patient Health Questionnaire

PPE: personal protective equipment

PSQI: Pittsburgh Sleep Quality Index 
SAS: Zung Self-Rating Anxiety Scale

SASR: the Stanford Acute Stress Reaction questionnaire

SCL-20: Symptom checklist depression scale

SCL-90: The Symptom Checklist-90-R

SDS: Zung Self-Rating Depression Scale

SF-36: Short Form Health Survey (SF-36)

sos: Stress Overload Scale

SSRS: Social Support Rating Scale

WHO: World Health Organisation

\section{Declarations}

\section{Ethics approval and consent to participate}

Not applicable

\section{Consent for publication}

Not applicable

\section{Availability of data and materials}

The datasets during and/or analysed during the current study available from the corresponding author on reasonable request

\section{Competing interests}

The authors declare that they have no competing interests

\section{Funding}

This project is funded by the Chief Science Office of the Scottish Government: RAPID RESEARCH IN COVID-19 PROGRAMME REF: $\mathrm{COV} / \mathrm{UHI} /$ Portfolio. The funding sources had no

role in the design or conduct of the study nor in the collection, management, analysis, and interpretation of the data; preparation, review, or approval of the manuscript; or decision to submit the manuscript for publication.

\section{Authors' contributions}

JDK, SAM and HL had the idea for the study. JDK, RP, CoM designed the search strategy. JDK, HL, LE screened abstracts and full texts. JDK, HL, LE, SAM, acquired data, and assessed risk of bias in studies. All authors interpreted the data analysis. JDK and HL wrote the manuscript, with revisions from all authors. The corresponding author attests that all listed authors meet authorship criteria.

\section{Acknowledgements}

Thank you to Abbie Oman (University of Aberdeen) for critically reviewing our manuscript.

\section{References}


(1) Gold JA. Covid-19: adverse mental health outcomes for healthcare workers. BMJ 2020;369:m1815. DOI: https://doiorg.knowledge.idm.oclc.org/10.1136/bmj.m1815

(2) Petrie K, Crawford J, Baker STE, Dean K, Robinson J, Veness BJ, et al. Interventions to reduce symptoms of common mental disorders and suicidal ideation in physicians: a systematic review and meta-analysis. The Lancet: Psychiatry 2019;6(3):225-234. DOI: http://dx.doi.org/10.1016/ S2215-0366(18)30509-1

(3) Nguyen LH, Drew DA, Graham MS, Joshi AD, Guo C, Ma W, et al. Risk of COVID-19 among front-line health-care workers and the general community: a prospective cohort study. The Lancet: Public health 2020;5(9):e475-e483. DOI: https://doi.org/10.1016/S24682667(20)30164-X

(4) Tawfik DS, Scheid A, Profit J, Shanafelt T, Trockel M, Adair KC, et al. Evidence relating health care provider burnout and quality of care: a systematic review and meta-analysis. Ann Intern Med 2019 10/15;171(8):555-567. DOI: 10.7326/M19-1152

(5) Maunder R, Lancee W, Balderson K, Bennett J, Borgundvaag B, Evans S, et al. Long-term psychological and occupational effects of providing hospital healthcare during SARS outbreak. Emerging Infect Dis 2006;12(12):1924-1932. DOI: 10.3201/eid1212.060584

(6) Brooks SK, Dunn R, Amlôt R, Rubin GJ, Greenberg N. A systematic, thematic review of social and occupational factors associated with psychological outcomes in healthcare employees during an infectious disease outbreak. J Occup Environ Med 2018;60(3):248-257. DOI: $10.1097 /$ JOM.0000000000001235

(7) Kisely S, Warren N, McMahon L, Dalais C, Henry I, Siskind D. Occurrence, prevention, and management of the psychological effects of emerging virus outbreaks on healthcare workers: rapid review and meta-analysis. BMJ 2020;369:m1642. DOI: https://doiorg.knowledge.idm.oclc.org/10.1136/bmj.m1642

(8) Spoorthy MS, Pratapa SK, Mahant S. Mental health problems faced by healthcare workers due to the COVID-19 pandemic-a review. Asian J Psychiatr 2020;51:102119. DOI: https://doi.org/10.1016/j.ajp.2020.102119

(9) Reger MA, Piccirillo ML, Buchman-Schmitt J. COVID-19, Mental health, and suicide risk among health care workers: looking beyond the crisis. J Clin Psychiatry 2020;81(5). DOI: 10.4088/JCP.20com13381

(10) Neto MLR, Almeida HG, Esmeraldo JD, Nobre CB, Pinheiro WR, de Oliveira C, et al. When health professionals look death in the eye: the mental health of professionals who deal daily with the 2019 coronavirus outbreak. Psychiatry Res 2020;288:112972. DOI: https://doi.org/10.1016/j.psychres.2020.112972

(11) British Medical Association. The mental health and wellbeing of the medical workforce - now and beyond COVID-19. 2020. Available from URL: https://www.bma.org.uk/media/2475/bma-covid-19-and-nhs-staff-mental-health-wellbeing-report-may-2020.pdf

(12) Melnyk BM, Kelly SA, Stephens J, Dhakal K, McGovern C, Tucker S, et al. Interventions to improve mental health, well-being, physical health, and lifestyle behaviors in physicians and nurses: a systematic review. American journal of health promotion 2020:089011712092045. DOl: https://doi-org.knowledge.idm.oclc.org/10.1177/0890117120920451

(13) United Nations. Policy Brief: COVID-19 and the need for action on mental health. 2020. Available from URL: https://unsdg.un.org/sites/default/files/2020-05/UN-Policy-Brief-COVID-19-and-mental-health.pdf

(14) Holmes EA, O'Connor RC, Perry VH, Tracey I, Wessely S, Arseneault L, et al. Multidisciplinary research priorities for the COVID-19 pandemic: a call for action for mental health science. The Lancet. Psychiatry: Lancet Psychiatry 2020;7(6):547-560. DOI: https://doi.org/10.1016/ S2215-0366(20)30168-1

(15) Brooks SK, Gerada C, Chalder T. Review of literature on the mental health of doctors: Are specialist services needed? J Ment Health 2011;20(2):146-156. DOI: https://doi-org.knowledge.idm.oclc.org/10.3109/09638237.2010.541300

(16) Tricco AC, Langlois EV, Straus SE. Rapid reviews to strengthen health policy and systems: a practical guide. Geneva: World Health Organisation; 2017. Available from URL: https://apps.who.int/iris/bitstream/handle/10665/258698/9789241512763-

eng.pdf;sequence $=1$ 
(17) Khangura S, Konnyu K, Cushman R, Grimshaw J, Moher D. Evidence summaries: the evolution of a rapid review approach. Syst Rev 2012;1(1):10-10. DOI: https://doi.org/10.1186/2046-4053-1-10

(18) Garritty C, Gartlehner G, Kamel C, King V, Nussbaumer-Streit B, Stevens A., et al. Cochrane rapid reviews. interim guidance from the Cochrane Rapid Reviews Methods Group. 2020. Available from URL:

https://methods.cochrane.org/rapidreviews/sites/methods.cochrane.org.rapidreviews/files/public/uploads/cochrane_rr_-_guidance23mar2020-final.pdf

(19) Moola S, Munn Z, Tufanaru C, Aromataris E, Sears K, Sfetcu R, et al. Chapter 7: Systematic reviews of etiology and risk. In: Aromataris E, Munn Z., editors. JBI Manual for Evidence Synthesis [Adelaide]: Joanna Briggs Institute; 2020. DOI: https://doi.org/10.46658/JBIMES-20-08

(20) Evidence Partners, CLARITY Group at McMaster University. Methodological resources: tools to assess risk of bias. 2020; Available from URL: https://www.evidencepartners.com/resources/methodological-resources/.

(21) CASP. Cohort Study Checklist. 2020. Available from URL: https://casp-uk.net/casp-tools-checklists/.

(22) Sterne JAC, Hernán M, Reeves BC, Savović J, Berkman ND, Viswanathan M, et al. ROBINS-l: a tool for assessing risk of bias in nonrandomized studies of interventions. BMJ 2016;355:i4919. DOI: 10.1136/bmj.i4919

(23) Lockwood C, Munn Z, Porritt K. Qualitative research synthesis: methodological guidance for systematic reviewers utilizing metaaggregation. Int J Evid Based Healthc 2015;13(3):179-187. DOI: 10.1097/XEB.0000000000000062

(24) Bartlett G, Vedel I, Hong QN, Pluye P, Rousseau M, Fàbregues S, et al. The Mixed Methods Appraisal Tool (MMAT) version 2018 for information professionals and researchers. Educ Inf 2018 10;34(4):285-291. DOI: 10.3233/EFI-180221

(25) Popay J, Roberts H, Sowden A, Petticrew M, Arai L, Rodgers M, et al. Guidance on the conduct of narrative synthesis in systematic reviews: a product from the ESRC Methods Programme 2006. Available from URL: https://www.lancaster.ac.uk/media/lancasteruniversity/content-assets/documents/fhm/dhr/chir/NSsynthesisguidanceVersion1-April2006.pdf

(26) Campbell M, Katikireddi SV, Sowden A, McKenzie JE, Thomson H. Improving Conduct and Reporting of Narrative Synthesis of Quantitative Data (ICONS-Quant): protocol for a mixed methods study to develop a reporting guideline. BMJ Open 2018;8(2):e020064. DOI: http://dx.doi.org/10.1136/bmjopen-2017-020064

(27) Schünemann HJ, Vist GE, Higgins JP, Santesso N, Deeks JJ, Paul Glasziou P, et al. Chapter 15: Interpreting results and drawing conclusions. In: Higgins JP, Thomas J, Chandler J, Cumpston M, Li T, Page MJ, et al, editors. Cochrane handbook for systematic reviews of interventions. 2nd ed.; 2019. p. 403-431. DOI: https://doi.org/10.1002/9781119536604.ch15

(28) Ahmed MA, Jouhar R, Ahmed N, Adnan S, Aftab M, Zafar MS, et al. Fear and practice modifications among dentists to combat novel coronavirus disease (COVID-19) outbreak. Int J Environ Res Public Health 2020;17(8):2821. DOI:

https://doi.org/10.3390/ijerph17082821

(29) Cai H, Tu B, Ma J, Chen L, Fu L, Jiang Y, et al. Psychological impact and coping strategies of frontline medical staff in Hunan between January and March 2020 during the outbreak of coronavirus disease 2019 (COVID-19) in Hubei, China. Med Sci Monit 2020;26:e924171. DOI: 10.12659/MSM.924171

(30) Cai W, Lian B, Song X, Hou T, Deng G, Li H. A cross-sectional study on mental health among health care workers during the outbreak of Corona Virus Disease 2019. Asian J Psychiatr 2020;51:102111-102111. DOI: https://doi.org/10.1016/j.ajp.2020.102111

(31) Cao J, Wei J, Zhu H, Duan Y, Geng W, Hong X, et al. A study of basic needs and psychological wellbeing of medical workers in the fever clinic of a tertiary general hospital in Beijing during the COVID-19 Outbreak. Psychother Psychosom 2020;89(4):252-254. DOI: DOI: $10.1159 / 000507453$

(32) Chew NW, Lee GK, Tan BY, Jing M, Goh Y, Ngiam NJH, et al. A multinational, multicentre study on the psychological outcomes and associated physical symptoms amongst healthcare workers during COVID-19 outbreak. Brain Behav Immun 2020;88:559-565. DOI: https://doi.org/10.1016/j.bbi.2020.04.049

Page $14 / 28$ 
(33) Chung JP, Yeung WS. Staff mental health self-assessment during the COVID-19 outbreak [Letter to editor]. East Asian Archives of Psychiatry 2020;30(1):34-34. DOI: https://doi.org/10.12809/eaap2014

(34) Huang, Y., \& Zhao, N. (2020). Generalized anxiety disorder, depressive symptoms and sleep quality during COVID-19 outbreak in China: a web-based cross-sectional survey. Psychiatry research 2020;288(112954):1-6. DOI: 10.1016/j.psychres.2020.112954

(35) Kang L, Ma S, Chen M, Yang J, Wang Y, Li R, et al. Impact on mental health and perceptions of psychological care among medical and nursing staff in Wuhan during the 2019 novel coronavirus disease outbreak: A cross-sectional study. Brain Behav Immun 2020;87:11-17. DOl: https://doi.org/10.1016/j.bbi.2020.03.028

(36) Lai J, Ma S, Wang Y, Cai Z, Hu J, Wei N, et al. Factors associated with mental health outcomes among health care workers exposed to coronavirus disease 2019. JAMA Network Open 2020;3(3):e203976. DOI: 10.1001/jamanetworkopen.2020.3976

(37) Liang Y, Chen M, Zheng X, Liu J. Screening for Chinese medical staff mental health by SDS and SAS during the outbreak of COVID19. J Psychosom Res 2020;133:110102-110102. DOI: https://doi.org/10.1016/j.jpsychores.2020.110102

(38) Lu W, Wang H, Lin Y, Li L. Psychological status of medical workforce during the COVID-19 pandemic: A cross-sectional study. Psychiatry Res 2020;288:112936-112936. DOl: https://doi.org/10.1016/j.psychres.2020.112936

(39) Mo Y, Deng L, Zhang L, Lang Q, Liao C, Wang N, et al. Work stress among Chinese nurses to support Wuhan in fighting against COVID-19 epidemic. J Nurs Manag 2020;28(5):1002-1009. DOI: 10.1111/jonm.13014

(40) Shacham M, Hamama-Raz Y, Kolerman R, Mijiritsky O, Ben-Ezra M, Mijiritsky E. COVID-19 factors and psychological factors associated with elevated psychological distress among dentists and dental hygienists in Israel. Int J Environ Res Public Health 2020;17(8):2900. DOI: https://doi.org/10.3390/ijerph17082900

(41) Sun N, Wei L, Shi S, Jiao D, Song R, Ma L, et al. A qualitative study on the psychological experience of caregivers of COVID-19 patients. Am J Infect Control 2020;48(6):592-598. DOI: https://doi.org/10.1016/j.ajic.2020.03.018

(42) Tan BY, Yeo LL, Sharma VK, Chew NW, Jing M, Goh Y, et al. Psychological impact of the COVID-19 pandemic on health care workers in Singapore. Ann Intern Med 2020 / 08 / 18 /;173(4):317-320. DOI: 10.7326/M20-1083

(43) Urooj U, Ansari A, Siraj A, Khan S, Tariq H. Expectations, fears and perceptions of doctors during Covid-19 Pandemic. Pakistan journal of medical sciences 2020;36:S37-S42. DOI: https://doi.org/10.12669/pjms.36.COVID19-S4.2643

(44) Wang S, Xie L, Xu Y, Yu S, Yao B, Xiang D. Sleep disturbances among medical workers during the outbreak of COVID-2019. Occup Med (Lond ) 2020;70(5):364-369. DOI: https://doi-org.knowledge.idm.oclc.org/10.1093/occmed/kqaa074

(45) Wu Y, Wang J, Luo C, Hu S, Lin X, Anderson AE, et al. A comparison of burnout frequency among oncology physicians and nurses working on the frontline and usual wards during the COVID-19 epidemic in Wuhan, China. J Pain Symptom Manage 2020;60(1):e60-e65. DOI: https://doi.org/10.1016/j.jpainsymman.2020.04.008

(46) Xiao H, Zhang Y, Kong D, Li S, Yang N. The effects of social support on sleep quality of medical staff treating patients with coronavirus disease 2019 (COVID-19) in January and February 2020 in China. Med Sci Monit 2020;26:e923549. DOl:

10.12659/MSM.923549

(47) Xu J, Xu Q, Wang C, Wang J. Psychological status of surgical staff during the COVID-19 outbreak. Psychiatry Res 2020;288:112955. DOI: https://doi.org/10.1016/j.psychres.2020.112955

(48) Yin X, Zeng L. A study on the psychological needs of nurses caring for patients with coronavirus disease 2019 from the perspective of the existence, relatedness, and growth theory. Int J Nurs Sci 2020;7(2):157-160. DOI: 10.1016/j.jpnss.2020.04.002

(49) Zhang W, Wang K, Yin L, Zhao W, Xue Q, Peng M, et al. Mental health and psychosocial problems of medical health workers during the COVID-19 epidemic in China. Psychother Psychosom 2020;89(4):1-9. DOI: https://doi.org/10.1159/000507639

(50) Li Z, Ge J, Yang M, Feng J, Qiao M, Jiang R, et al. Vicarious traumatization in the general public, members, and non-members of medical teams aiding in COVID-19 control. Brain Behav Immun 2020;88:916-919. DOI: https://doi.org/10.1016/j.bbi.2020.03.007

Page 15/28 
(51) Balakumar C, Rait J, Montauban P, Zarsadias P, Iqbal S, Fernandes R. COVID-19: are frontline surgical staff ready for this? Br J Surg 2020;107(7):e195-e195. DOI:10.1002/bjs.11663

(52) Markwell A, Mitchell R, Wright AL, Brown AF. Clinical and ethical challenges for emergency departments during communicable disease outbreaks: Can lessons from Ebola Virus Disease be applied to the COVID-19 pandemic? Emerg Med Australas 2020;32(3):520524. DOI: https://doi-org.knowledge.idm.oclc.org/10.1111/1742-6723.13514

(53) Grace SL, Hershenfield K, Robertson E, Stewart DE. The occupational and psychosocial impact of SARS on academic physicians in three affected hospitals. Psychosomatics 2005 September-October 2005;46(5):385-391. DOI:

https://doi.org/10.1176/appi.psy.46.5.385

(54) Comas-Herrera A, Zalakain J, Litwin C, Hsu AT, Lane N, Fernández J. Mortality associated with COVID-19 outbreaks in care homes: early international evidence. 2020. Available from URL: https://ltccovid.org/2020/04/12/mortality-associated-with-covid-19-outbreaksin-care-homes-early-international-evidence/

(55) Ortolan A, Lorenzin M, Felicetti M, Doria A, Ramonda R. Does gender influence clinical expression and disease outcomes in COVID19? A systematic review and meta-analysis. International journal of infectious diseases 2020;99:496-504. DOl:

https://doi.org/10.1016/j.jijid.2020.07.076

(56) Pérez-López FR, Tajada M, Savirón-Cornudella R, Sánchez-Prieto M, Chedraui P, Terán E. Coronavirus disease 2019 and genderrelated mortality in European countries: A meta-analysis. Maturitas 2020; 141:59-62;141:59-62. DOI:

https://doi.org/10.1016/j.maturitas.2020.06.017

(57) Boniol M, Mclsaac M, Xu L, Wuliji T, Diallo K, Campbell J. Gender equity in the health workforce: analysis of 104 countries. 2019. Available from URL: https://www.who.int/hrh/resources/gender_equity-health_workforce_analysis/en/

(58) Al Knawy BA, Al-Kadri H, Elbarbary M, Arabi Y, Balkhy HH, Clark A. Perceptions of postoutbreak management by management and healthcare workers of a Middle East respiratory syndrome outbreak in a tertiary care hospital: a qualitative study. BMJ Open; BMJ Open 2019;9(5):e017476. DOI: http://dx.doi.org/10.1136/bmjopen-2017-017476

(59) Montgomery A, Panagopoulou E, Esmail A, Richards T, Maslach C. Burnout in healthcare: the case for organisational change. BMJ 2019;366:I4774. DOI: https://doi.org/10.1136/bmj.14774

(60) Aldridge RW, Lewer D, Katikireddi SV, Mathur R, Pathak N, Burns R, et al. Black, Asian and Minority Ethnic groups in England are at increased risk of death from COVID-19: indirect standardisation of NHS mortality data. Wellcome open research 2020;5:88. DOI: https://doi.org/10.12688/wellcomeopenres.15922.2

(61) Tai DB, Shah A, Doubeni CA, Sia IG, Wieland ML. The disproportionate impact of COVID-19 on racial and ethnic minorities in the United States. Clinical infectious diseases 2020. DOI: https://doi-org.knowledge.idm.oclc.org/10.1093/cid/ciaa815

(62) APM Research Lab. The color of coronavirus: COVID-19 deaths by race and ethnicity in the US. 2020. Available from URL: https://www.apmresearchlab.org/covid/deaths-by-race

(63) Zhang X, Clarke CL, Rhynas SJ. A thematic analysis of Chinese people with dementia and family caregivers' experiences of home care in China. Dementia (London, England) 2019:147130121986146. DOI: https://doi-

org.knowledge.idm.oclc.org/10.1177/1471301219861466

(64) Burchell B, Wang S, Kamerāde D, Bessa I, Rubery J. Cut hours, not people: no work, furlough, short hours and mental health during the COVID-19 pandemic in the UK. 2020. Available from URL: https://www.cbr.cam.ac.uk/fileadmin/user_upload/centre-for-businessresearch/downloads/working-papers/wp521.pdf

(65) Gentilini U, Almenfi M, Orton I, Dale P. Social Protection and Jobs Responses to COVID-19: A Real-Time Review of Country Measures. 2020. Available from URL: https://openknowledge.worldbank.org/handle/10986/33635

\section{Tables}

Table 1: Study Characteristics 


\begin{tabular}{|c|c|c|c|c|c|c|}
\hline & Author & Design & Country & Participants & Selection method & Measures \\
\hline 1 & $\begin{array}{l}\text { Ahmed et } \\
\text { al., } \\
(2020) \text { (1) }\end{array}$ & $\begin{array}{l}\text { Cross- } \\
\text { sectional }\end{array}$ & $\begin{array}{l}\text { Global } \\
\text { (30 countries) }\end{array}$ & $\mathrm{n}=650$ & $\begin{array}{l}\text { Online questionnaire } \\
\text { distributed via email and } \\
\text { social media to dental } \\
\text { professionals worldwide. }\end{array}$ & $\begin{array}{l}\text { Validated } \\
\text { questionnaire: } \\
22 \text { closed-ended } \\
\text { questions } \\
\text { divided into two } \\
\text { sections. (Fear } \\
\text { \& Clinical } \\
\text { practices) }\end{array}$ \\
\hline 2 & $\begin{array}{l}\text { Balakumar } \\
\text { et al., } \\
(2020) \\
(2)\end{array}$ & $\begin{array}{l}\text { Uncontrolled } \\
\text { before and } \\
\text { after study. }\end{array}$ & UK & $\begin{array}{l}\mathrm{n}=27 \\
\text { (Surgeons) }\end{array}$ & $\begin{array}{l}\text { Pre- and post-training } \\
\text { surveys distributed to a } \\
\text { surgical team. }\end{array}$ & $\begin{array}{l}\text { Pre- and post- } \\
\text { training surveys }\end{array}$ \\
\hline 3 & $\begin{array}{l}\text { H.Cai et al., } \\
(2020) \\
(3)\end{array}$ & $\begin{array}{l}\text { Cross- } \\
\text { sectional }\end{array}$ & $\begin{array}{l}\text { China } \\
\text { Hunan }\end{array}$ & $\begin{array}{l}\mathrm{n}=534 \\
\text { (Frontline medical } \\
\text { workers) }\end{array}$ & $\begin{array}{l}\text { Questionnaires sent to } \\
\text { frontline medical staff in } \\
\text { Hunan province between } \\
\text { January and March } 2020 \text {. }\end{array}$ & $\begin{array}{l}\text { Five-section } \\
\text { questionnaire }\end{array}$ \\
\hline 4 & $\begin{array}{l}\text { W.Cai et al., } \\
(2020)(4)\end{array}$ & $\begin{array}{l}\text { Cross- } \\
\text { sectional }\end{array}$ & $\begin{array}{l}\text { China } \\
\text { Jiangsu Province }\end{array}$ & $\begin{array}{l}\mathrm{n}=1521 \\
(147 \text { experienced } \\
\text { in public health } \\
\text { emergencies } \\
(\mathrm{PHE}))\end{array}$ & $\begin{array}{l}\text { Health care workers } \\
\text { recruited but method } \\
\text { unclear. }\end{array}$ & $\begin{array}{l}\text { SCL-90 } \\
\text { CD-RISC } \\
\text { SSRS }\end{array}$ \\
\hline 5 & $\begin{array}{l}\text { Cao et al., } \\
(2020) \\
(5)\end{array}$ & $\begin{array}{l}\text { Mixed } \\
\text { methods }\end{array}$ & $\begin{array}{l}\text { China } \\
\text { Beijing }\end{array}$ & $\begin{array}{l}\mathrm{n}=37 \\
(16 \text { Doctors, } 19 \\
\text { Nurses, and } \\
2 \text { Technicians } \\
\text { within a COVID-19 } \\
\text { clinic) }\end{array}$ & $\begin{array}{l}\text { Qualitative and Quantitative } \\
\text { evaluations of staff in a fever } \\
\text { clinic. Staff had been } \\
\text { handpicked based on their } \\
\text { 'experience, adaptability and } \\
\text { tenacity under pressure in } \\
\text { past works' }\end{array}$ & $\begin{array}{l}\text { PHQ-9 } \\
\text { MBI } \\
\text { Qualitative } \\
\text { interviews }\end{array}$ \\
\hline 6 & $\begin{array}{l}\text { Chew et al., } \\
(2020) \text { (6) }\end{array}$ & $\begin{array}{l}\text { Cross- } \\
\text { sectional }\end{array}$ & $\begin{array}{l}\text { Singapore \& } \\
\text { India }\end{array}$ & $\begin{array}{l}\mathrm{n}=906 \\
\text { (480 HCW's from } \\
\text { a Singapore } \\
\text { Hospital) }\end{array}$ & $\begin{array}{l}\text { HCWs from } 5 \text { major } \\
\text { hospitals invited to } \\
\text { participated in a } \\
\text { questionnaire between Feb } \\
2019 \text { - April } 2020 .\end{array}$ & $\begin{array}{l}\text { DASS-21, } \\
\text { IES-R } \\
\text { Symptom } \\
\text { questionnaire }\end{array}$ \\
\hline 7 & $\begin{array}{l}\text { Chung \& } \\
\text { Yeung, } \\
(2020)(7)\end{array}$ & $\begin{array}{l}\text { Cross- } \\
\text { sectional }\end{array}$ & $\begin{array}{l}\text { China } \\
\text { Hong Kong }\end{array}$ & $\begin{array}{l}\mathrm{n}=69 \\
\text { (HCWs: } 69 / 8418 \\
\text { full-time hospital } \\
\text { staff) }\end{array}$ & $\begin{array}{l}\text { Online mental health self- } \\
\text { assessment questionnaire } \\
\text { distributed to all hospital } \\
\text { staff in the Hong Kong East } \\
\text { Cluster. }\end{array}$ & PHQ-9 \\
\hline 8 & $\begin{array}{l}\text { Huang \& } \\
\text { Zhao, } \\
(2020) \\
(8)\end{array}$ & $\begin{array}{l}\text { Cross- } \\
\text { sectional }\end{array}$ & $\begin{array}{l}\text { China } \\
\text { Nationwide }\end{array}$ & $\begin{array}{l}\mathrm{n}=603 \\
(31.1 \% \mathrm{HCWs})\end{array}$ & $\begin{array}{l}\text { Web-based survey of general } \\
\text { population, invited via social } \\
\text { media, random recruitment - } \\
\text { all Chinese people using } \\
\text { WeChat may have seen it. }\end{array}$ & $\begin{array}{l}\text { Web-based } \\
\text { survey. } \\
\text { PSQI, GAD, CES- } \\
\text { D }\end{array}$ \\
\hline 9 & $\begin{array}{l}\text { Kang et al., } \\
(2020) \text { (9) }\end{array}$ & $\begin{array}{l}\text { Cross- } \\
\text { sectional }\end{array}$ & $\begin{array}{l}\text { China } \\
\text { Wuhan }\end{array}$ & $\begin{array}{l}\mathrm{n}=994 \\
\text { (Doctors and } \\
\text { Nurses) }\end{array}$ & $\begin{array}{l}\text { Questionnaire distributed } \\
\text { online to doctors or nurses } \\
\text { working in Wuhan. }\end{array}$ & $\begin{array}{l}\text { PHQ-9 } \\
\text { GAD-7 } \\
\text { ISI } \\
\text { IES-R }\end{array}$ \\
\hline 10 & $\begin{array}{l}\text { Lai et al., } \\
(2020) \quad(10)\end{array}$ & $\begin{array}{l}\text { Cross- } \\
\text { sectional }\end{array}$ & $\begin{array}{l}\text { China } \\
\text { (Nationwide but } \\
60 \% \text { from } \\
\text { Wuhan) }\end{array}$ & $\begin{array}{l}\mathrm{n}=1257 \\
\text { (Nurses and } \\
\text { Doctors in } 34 \\
\text { hospitals/fever } \\
\text { clinics) }\end{array}$ & $\begin{array}{l}\text { Hospital based survey via } \\
\text { region-stratified 2-stage } \\
\text { cluster sampling from Jan } 29 \\
2020 \text { - Feb } 32020 .\end{array}$ & $\begin{array}{l}\text { PHQ-9 } \\
\text { GAD } \\
\text { ISI } \\
\text { IES-R }\end{array}$ \\
\hline 11 & $\begin{array}{l}\text { Li et al., } \\
(2020)(11)\end{array}$ & $\begin{array}{l}\text { Cross- } \\
\text { sectional }\end{array}$ & $\begin{array}{l}\text { China } \\
\text { Wuhan }\end{array}$ & $\begin{array}{l}\mathrm{n}=740 \\
(214 \text { general } \\
\text { population and } \\
526 \text { Nurses) }\end{array}$ & $\begin{array}{l}\text { Mobile app-based } \\
\text { questionnaire of general } \\
\text { public and nurses in Wuhan. }\end{array}$ & $\begin{array}{l}\text { Vicarious } \\
\text { Trauma } \\
\text { Questionnaire } \\
\text { (Chinese } \\
\text { version) }\end{array}$ \\
\hline 12 & $\begin{array}{l}\text { Liang, } \\
\text { Chen, } \\
\text { Zheng, \& } \\
\text { Li, } \\
(2020) \quad(12)\end{array}$ & $\begin{array}{l}\text { Cross- } \\
\text { sectional }\end{array}$ & $\begin{array}{l}\text { China } \\
\text { Guangdong } \\
\text { Province }\end{array}$ & $\begin{array}{l}\mathrm{n}=59 \\
\text { (23 Doctors and } \\
36 \text { Nurses } \\
\text { from COVID-19 } \\
\text { department and } \\
21 \text { HCWs from } \\
\text { other } \\
\text { departments) }\end{array}$ & $\begin{array}{l}\text { Questionnaire distributed to } \\
\text { medical staff in a hospital. } \\
\text { Method of distribution } \\
\text { unclear. }\end{array}$ & $\begin{array}{l}\text { SDS } \\
\text { SAS }\end{array}$ \\
\hline
\end{tabular}

Page 17/28 


\begin{tabular}{|c|c|c|c|c|c|c|}
\hline 13 & $\begin{array}{l}\text { Lu, Wang, } \\
\text { Lin \& Li, } \\
(2020)(13)\end{array}$ & $\begin{array}{l}\text { Cross- } \\
\text { sectional }\end{array}$ & $\begin{array}{l}\text { China } \\
\text { Fujian }\end{array}$ & $\begin{array}{l}\mathrm{n}=2299 \\
\text { (2042 Medical and } \\
257 \text { admin staff) }\end{array}$ & $\begin{array}{l}\text { Questionnaire survey of } \\
\text { medical staff in a provincial } \\
\text { hospital in Feb } 2020 .\end{array}$ & $\begin{array}{l}\text { NRS } \\
\text { HAMA } \\
\text { HAMD }\end{array}$ \\
\hline 14 & $\begin{array}{l}\text { Mo et al., } \\
(2020)(14)\end{array}$ & $\begin{array}{l}\text { Cross- } \\
\text { sectional }\end{array}$ & $\begin{array}{l}\text { China } \\
\text { Wuhan }\end{array}$ & $\begin{array}{l}\mathrm{n}=180 \\
\text { (Nurses from } \\
\text { Guangxi } \\
\text { supporting } \\
\text { COVID-19 in } \\
\text { Wuhan) }\end{array}$ & $\begin{array}{l}\text { Convenient sampling of } \\
\text { nurses from Guangxi } \\
\text { recruited to support COVID- } \\
19 \text { work in Wuhan. } 85.71 \% \\
\text { response rate of } 180 \text { nurses } \\
\text { sampled. }\end{array}$ & $\begin{array}{l}\text { SOS } \\
\text { SAS }\end{array}$ \\
\hline 15 & $\begin{array}{l}\text { Shacham et } \\
\text { al., (2020) } \\
(15)\end{array}$ & $\begin{array}{l}\text { Cross- } \\
\text { sectional }\end{array}$ & Israel & $\begin{array}{l}\mathrm{n}=338 \\
\text { (Dental hygienists } \\
\text { and Dentists) }\end{array}$ & $\begin{array}{l}\text { Dental hygienists and } \\
\text { dentists, approached using } \\
\text { social media, mailing lists } \\
\text { and forums. }\end{array}$ & $\begin{array}{l}\text { Demands Scale } \\
\text {-Short Version } \\
\text { GSES } \\
\text { Kessler K6 }\end{array}$ \\
\hline 16 & $\begin{array}{l}\text { Sun et al., } \\
(2020) \\
(16)\end{array}$ & Qualitative & $\begin{array}{l}\text { China } \\
\text { Henan (One } \\
\text { hospital) }\end{array}$ & $\begin{array}{l}\mathrm{n}=20 \\
\text { (Nurses/17 } \\
\text { Female) }\end{array}$ & $\begin{array}{l}\text { Purposeful sampling of } \\
\text { nurses caring for COVID-19 } \\
\text { patients in a hospital. } \\
\text { Jan/Feb } 2020 .\end{array}$ & $\begin{array}{l}\text { Semi-structured } \\
\text { interviews }\end{array}$ \\
\hline 17 & $\begin{array}{l}\text { Tan et al., } \\
(2020) \\
(17)\end{array}$ & $\begin{array}{l}\text { Cross- } \\
\text { sectional }\end{array}$ & $\begin{array}{l}\text { Singapore } \\
\text { (Two tertiary } \\
\text { hospitals) }\end{array}$ & $\begin{array}{l}\mathrm{n}=470 \\
\text { (HCWs - medical } \\
\text { and non-medical) }\end{array}$ & $\begin{array}{l}\text { HCWs from two major } \\
\text { tertiary hospitals in } \\
\text { Singapore invited to } \\
\text { participate, Feb/March } 2020\end{array}$ & $\begin{array}{l}\text { DASS-21 } \\
\text { IES-R }\end{array}$ \\
\hline 18 & $\begin{array}{l}\text { Urooj et al., } \\
(2020) \\
(18)\end{array}$ & $\begin{array}{l}\text { Mixed } \\
\text { Method }\end{array}$ & Pakistan & $\begin{array}{l}\mathrm{n}=222 \\
(134 \text { without } \\
\text { COVID-19 patients } \\
\text { and } \\
150 \text { female })\end{array}$ & $\begin{array}{l}\text { Purposive sampling of } 250 \\
\text { clinicians from a range of } \\
\text { specialities and seniority. } \\
222 \text { responded }(88.8 \%)\end{array}$ & $\begin{array}{l}\text { Doctors fears } \\
\text { and expectations }\end{array}$ \\
\hline 19 & $\begin{array}{l}\text { Wang et al., } \\
\text { (2020) } \\
(19)\end{array}$ & $\begin{array}{l}\text { Cross- } \\
\text { sectional }\end{array}$ & $\begin{array}{l}\text { China } \\
\text { Wuhan }\end{array}$ & $\begin{array}{l}\mathrm{n}=123 \\
\text { (HCWs in a } \\
\text { Paediatric centre) }\end{array}$ & $\begin{array}{l}\text { Questionnaire survey } \\
\text { conducted at a paediatric } \\
\text { centre in Wuhan. 50\% of all } \\
\text { HCWs responded \& were } \\
\text { included. }\end{array}$ & $\begin{array}{l}\text { PSQI } \\
\text { SAS } \\
\text { SDS }\end{array}$ \\
\hline 20 & $\begin{array}{l}\text { Wu et al., } \\
(2020) \\
(20)\end{array}$ & $\begin{array}{l}\text { Cross- } \\
\text { sectional }\end{array}$ & $\begin{array}{l}\text { China } \\
\text { Wuhan }\end{array}$ & $\begin{array}{l}\mathrm{n}=190 \\
\text { (Hubai cancer } \\
\text { hospital - all from } \\
\text { oncology } \\
\text { 1:1 ratio frontline } \\
\text { vs usual wards) }\end{array}$ & $\begin{array}{l}220 \text { physicians and nurses } \\
\text { from Hubai cancer hospital } \\
\text { invited in March 2020.190 } \\
\text { included. }\end{array}$ & MBI \\
\hline 21 & $\begin{array}{l}\text { Xiao et al., } \\
(2020) \\
(21)\end{array}$ & $\begin{array}{l}\text { Cross- } \\
\text { sectional }\end{array}$ & $\begin{array}{l}\text { China } \\
\text { Wuhan }\end{array}$ & $\begin{array}{l}\mathrm{n}=180 \\
(54 \% \text { Nurses and } \\
45.6 \% \text { Doctors } \\
\text { from a respiratory } \\
\text { medicine/ fever } \\
\text { clinic) }\end{array}$ & $\begin{array}{l}\text { Unclear how participants } \\
\text { were sampled. All were } \\
\text { medical staff who treated } \\
\text { COVID-19 patients in } \\
\text { Jan/Feb } 2020 .\end{array}$ & $\begin{array}{l}\text { SAS } \\
\text { GSES } \\
\text { SASR } \\
\text { PSQI } \\
\text { SSRS }\end{array}$ \\
\hline 22 & $\begin{array}{l}\text { Xu, Xu, } \\
\text { Wang \& } \\
\text { Wang, } \\
(2020) \\
(22)\end{array}$ & Longitudinal & $\begin{array}{l}\text { China } \\
\text { Shanghai }\end{array}$ & $\begin{array}{l}\mathrm{n}=120 \\
\text { (Surgical staff. } \\
\text { One hospital } \\
\text { split into two } \\
\text { groups of } 60 \\
\text { Grp 1 - Jan-Feb } \\
\text { (outbreak period) } \\
\text { Grp 2 - March } \\
\text { (non-outbreak) }\end{array}$ & $\begin{array}{l}\begin{array}{l}\text { Surgical medical staff } \\
\text { sampled. }\end{array} \\
\end{array}$ & $\begin{array}{l}\text { Anxiety scale } \\
\text { Depression } \\
\text { score } \\
\text { Dream anxiety } \\
\text { score } \\
\text { SF-36 scale }\end{array}$ \\
\hline 23 & $\begin{array}{l}\text { Yin \& Zeng, } \\
(2020) \\
(23)\end{array}$ & $\begin{array}{l}\text { Qualitative - } \\
\text { in-depth } \\
\text { interviews }\end{array}$ & $\begin{array}{l}\text { China } \\
\text { Wuhan }\end{array}$ & $\begin{array}{l}\mathrm{n}=10 \\
\text { (Nurses at the } \\
\text { front-line; having } \\
\text { cared for COVID- } \\
19 \text { patients }>1 \\
\text { week) }\end{array}$ & Purposive sampling & \\
\hline 24 & $\begin{array}{l}\text { Zhang et } \\
\text { al., (2020) } \\
(24)\end{array}$ & $\begin{array}{l}\text { Cross - } \\
\text { sectional }\end{array}$ & $\begin{array}{l}\text { China } \\
\text { Nationwide }\end{array}$ & $\begin{array}{l}\mathrm{n}=2182 \\
\text { (927 Medical } \\
\text { HCWs; } 680 \\
\text { Doctors and } 247 \\
\text { Nurses, } \\
1255 \text { non-medical } \\
\text { HCWs) }\end{array}$ & $\begin{array}{l}\text { Random sampling - anyone } \\
\text { in China > } 16 \text { years were } \\
\text { welcome to join using an } \\
\text { online platform. }\end{array}$ & $\begin{array}{l}\text { ISI } \\
\text { SCL-90-R } \\
\text { PHQ-4 } \\
\text { Chinese versions }\end{array}$ \\
\hline
\end{tabular}

Measures Description 
Depression: CES-D: Centre for Epidemiologic Studies Depression Scale, HAM-D: Hamilton Depression Rating Scale, PHQ-9: Patient Health Questionnaire, SCL-20: Symptom checklist depression scale, SDS: Zung Self-Rating Depression Scale,

Anxiety: GAD-7: Generalised Anxiety Disorder Questionnaire, HAM-A: Hamilton Anxiety Rating Scale, SAS: Zung Self-Rating Anxiety Scale Stress: SOS: Stress Overload Scale

Depression \& Anxiety: DASS-21: Depression, Anxiety and Stress Scale, PHQ-4: Patient Health Questionnaire-4,

Sleep: PSQI: Pittsburgh Sleep Quality Index, ISI: Insomnia Severity Index

Others: CD-RISC: Connor-Davidson Resilience Scale, Demands Scale-Short Version, Dream anxiety score, GSES: Generalised self-efficacy scale, IES-R: Impact of Event Scale, Kessler K6 Distress Scale, MBI: Maslach Burnout Inventory, SASR: the Stanford Acute Stress Reaction questionnaire, SCL-90: The Symptom Checklist-90-R, SF-36: Short Form Health Survey, SSRS: Social Support Rating Scale, Vicarious Trauma Questionnaire

1. Ahmed MA, Jouhar R, Ahmed N, Adnan S, Aftab M, Zafar MS, et al. Fear and Practice Modifications among Dentists to Combat Novel Coronavirus Disease (COVID-19) Outbreak. International Journal of Environmental Research and Public Health. 2020;17(8):2821.

2. Balakumar C, Rait J, Montauban P, Zarsadias P, Iqbal S, Fernandes R. COVID-19: are frontline surgical staff ready for this? British Journal of Surgery. 2020.

3. Cai H, Tu B, Ma J, Chen L, Fu L, Jiang Y, et al. Psychological Impact and Coping Strategies of Frontline Medical Staff in Hunan Between January and March 2020 During the Outbreak of Coronavirus Disease 2019 (COVID-19) in Hubei, China. Medical Science Monitor: International Medical Journal of Experimental and Clinical Research. 2020;26:e924171-1. 4. Cai W, Lian B, Song X, Hou T, Deng G, Li H. A cross-sectional study on mental health among health care workers during the outbreak of Corona Virus Disease 2019. Asian Journal of Psychiatry. 2020;51:102111.

5. Cao J, Wei J, Zhu H, Duan Y, Geng W, Hong X, et al. A study of basic needs and psychological wellbeing of medical workers in the fever clinic of a tertiary general hospital in Beijing during the COVID-19 outbreak. Psychotherapy and Psychosomatics. 2020:1.

6. Chew NWS, Lee GKH, Tan BYQ, Jing M, Goh Y, Ngiam NJH, et al. A multinational, multicentre study on the psychological outcomes and associated physical symptoms amongst healthcare workers during COVID-19 outbreak. Brain, Behavior, and Immunity. 2020.

7. $\quad$ Chung JPY, Yeung WS. Staff Mental Health Self-Assessment During the COVID-19 Outbreak. East Asian Archives of Psychiatry: Official Journal of the Hong Kong College of Psychiatrists= Dong Ya Jing Shen ke xue zhi: Xianggang Jing Shen ke yi xue Yuan qi kan. 2020;30(1):34-.

8. Huang Y, Zhao N. Generalized anxiety disorder, depressive symptoms and sleep quality during COVID-19 epidemic in China: a web-based cross-sectional survey. medRxiv. 2020.

9. Kang L, Ma S, Chen M, Yang J, Wang Y, Li R, et al. Impact on mental health and perceptions of psychological care among medical and nursing staff in Wuhan during the 2019 novel coronavirus disease outbreak: A cross-sectional study. Brain, behavior, and immunity. 2020.

10. Lai J, Ma S, Wang Y, Cai Z, Hu J, Wei N, et al. Factors associated with mental health outcomes among health care workers exposed to coronavirus disease 2019. JAMA network open. 2020;3(3):e203976-e.

11. Li Z, Ge J, Yang M, Feng J, Qiao M, Jiang R, et al. Vicarious traumatization in the general public, members, and non-members of medical teams aiding in COVID-19 control. Brain, behavior, and immunity. 2020.

12. Liang Y, Chen M, Zheng X, Liu J. Screening for Chinese medical staff mental health by SDS and SAS during the outbreak of COVID-19. Journal of Psychosomatic Research. 2020;133:110102.

13. Lu W, Wang H, Lin Y, Li L. Psychological status of medical workforce during the COVID-19 pandemic: A crosssectional study. Psychiatry Research. 2020:112936.

14. Mo Y, Deng L, Zhang L, Lang Q, Liao C, Wang N, et al. Work stress among Chinese nurses to support Wuhan for fighting against the COVID-19 epidemic. Journal of nursing management. 2020.

15. Shacham M, Hamama-Raz Y, Kolerman R, Mijiritsky O, Ben-Ezra M, Mijiritsky E. COVID-19 Factors and Psychological Factors Associated with Elevated Psychological Distress among Dentists and Dental Hygienists in Israel. International Journal of Environmental Research and Public Health. 2020;17(8):2900.

16. Sun N, Shi S, Jiao D, Song R, Ma L, Wang H, et al. A Qualitative Study on the Psychological Experience of Caregivers of COVID-19 Patients. American Journal of Infection Control. 2020.

17. Tan BYQ, Chew NWS, Lee GKH, Jing M, Goh Y, Yeo LLL, et al. Psychological Impact of the COVID-19 Pandemic on Health Care Workers in Singapore. Annals of Internal Medicine. 2020.

18. Urooj U, Ansari A, Siraj A, Khan S, Tariq H. Expectations, Fears and Perceptions of doctors during Covid-19 Pandemic. Pakistan Journal of Medical Sciences. 2020;36(COVID19-S4).

19. Wang C, Pan R, Wan X, Tan Y, Xu L, Ho CS, et al. Immediate psychological responses and associated factors during the initial stage of the 2019 coronavirus disease (COVID-19) epidemic among the general population in China. International journal of environmental research and public health. 2020;17(5):1729.

Page $19 / 28$ 
20. Wu Y, Wang J, Luo C, Hu S, Lin X, Anderson AE, et al. A comparison of burnout frequency among oncology physicians and nurses working on the front lines and usual wards during the COVID-19 epidemic in Wuhan, China. Journal of Pain and Symptom Management. 2020.

21. Xiao H, Zhang Y, Kong D, Li S, Yang N. The effects of social support on sleep quality of medical staff treating patients with coronavirus disease 2019 (COVID-19) in January and February 2020 in China. Medical science monitor: international medical journal of experimental and clinical research. 2020;26:e923549-1.

22. Xu J, Xu Q-h, Wang C-m, Wang J. Psychological status of surgical staff during the COVID-19 outbreak. Psychiatry Research. 2020:112955.

23. Yin X, Zeng L. A study on the psychological needs of nurses caring for patients with coronavirus disease 2019 from the perspective of the existence, relatedness, and growth theory. International Journal of Nursing Sciences. 2020. 24. Zhang W-r, Wang K, Yin L, Zhao W-f, Xue Q, Peng M, et al. Mental health and psychosocial problems of medical health workers during the COVID-19 epidemic in China. Psychotherapy and psychosomatics. 2020:1-9.

Table 2: Risk of bias and quality assessment summary 


\begin{tabular}{|c|c|c|c|c|c|c|c|c|c|c|c|}
\hline & Author & $\begin{array}{l}\text { Participants } \\
\text { and setting } \\
\text { described } \\
\text { in detail, } \\
\text { including } \\
\text { similarity of } \\
\text { controls }\end{array}$ & $\begin{array}{l}\text { Criteria } \\
\text { for } \\
\text { inclusion } \\
\text { clearly } \\
\text { defined } \\
\text { and } \\
\text { exposures } \\
\text { similarly } \\
\text { measured }\end{array}$ & $\begin{array}{l}\text { Exposure } \\
\text { measured } \\
\text { in valid } \\
\text { and } \\
\text { reliable } \\
\text { way }\end{array}$ & $\begin{array}{l}\text { Objective, } \\
\text { standard } \\
\text { criteria used } \\
\text { for } \\
\text { measurement } \\
\text { of condition }\end{array}$ & $\begin{array}{l}\text { Confounding } \\
\text { factors } \\
\text { identified }\end{array}$ & $\begin{array}{l}\text { Strategies } \\
\text { to deal with } \\
\text { confounding } \\
\text { factors } \\
\text { stated }\end{array}$ & $\begin{array}{l}\text { Outcomes } \\
\text { measured } \\
\text { in valid } \\
\text { and } \\
\text { reliable } \\
\text { way }\end{array}$ & $\begin{array}{l}\text { Appropriate } \\
\text { statistical } \\
\text { analysis } \\
\text { used? }\end{array}$ & $\begin{array}{l}\text { JBI } \\
\text { Score } \\
(1)\end{array}$ & $\begin{array}{l}\text { Risk } \\
\text { of } \\
\text { Bias } \\
(2)\end{array}$ \\
\hline 1 & $\begin{array}{l}\text { Ahmed et } \\
\text { al., } \\
2020 \text { (3) } \\
\end{array}$ & + & + & + & + & + & - & ? & + & 6 & Low \\
\hline 2 & $\begin{array}{l}\text { Balakumar } \\
\text { et al., } \\
2020 \text { (4) }\end{array}$ & \multicolumn{9}{|c|}{ Risk of bias of uncontrolled before-after studies (assessed with ROBINS - I) (5): Low quality evidence } & \\
\hline 3 & $\begin{array}{l}\text { H. Cai et } \\
\text { al., } \\
2020 \text { (6) }\end{array}$ & + & + & + & - & + & - & + & + & 6 & Low \\
\hline 4 & $\begin{array}{l}\text { W. Cai et } \\
\text { al., } \\
2020 \text { (7) }\end{array}$ & + & + & + & + & + & - & + & + & 7 & Low \\
\hline $\bar{j}$ & $\begin{array}{l}\text { Cao et al., } \\
2020(8)\end{array}$ & \multicolumn{8}{|c|}{$\begin{array}{l}\text { Mixed methods appraisal tool (MMAT) used (Hong et al., 2018) S1-2 not addressed satisfactory: Low quality } \\
\text { evidence }\end{array}$} & & \\
\hline 5 & $\begin{array}{l}\text { Chew et } \\
\text { al., } \\
2020 \text { (9) }\end{array}$ & + & + & + & + & + & + & + & + & 8 & Low \\
\hline 7 & $\begin{array}{l}\text { Chung \& } \\
\text { Yeung, } \\
2020(10)\end{array}$ & + & - & + & + & - & - & - & - & 3 & High \\
\hline 8 & $\begin{array}{l}\text { Huang \& } \\
\text { Zhao, } \\
2020 \text { (11) } \\
\end{array}$ & + & + & + & + & + & - & + & + & 7 & Low \\
\hline 9 & 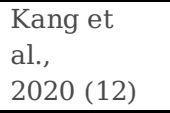 & + & + & + & + & + & + & - & + & 7 & Low \\
\hline 10 & $\begin{array}{l}\text { Lai et al., } \\
2020(13)\end{array}$ & + & + & + & + & + & - & + & + & 7 & Low \\
\hline$\overline{11}$ & $\begin{array}{l}\text { Li et al., } \\
2020(14)\end{array}$ & + & + & + & + & + & - & + & + & 7 & Low \\
\hline 12 & $\begin{array}{l}\text { Liang et } \\
\text { al., } \\
2020 \text { (15) } \\
\end{array}$ & - & - & + & + & - & - & + & + & 4 & High \\
\hline 13 & $\begin{array}{l}\text { Lu et al., } \\
2020(16)\end{array}$ & + & + & + & + & + & - & + & + & 7 & Low \\
\hline$\overline{14}$ & $\begin{array}{l}\text { Mo et al., } \\
2020(17)\end{array}$ & + & - & + & + & + & - & + & + & 6 & Minor \\
\hline 15 & $\begin{array}{l}\text { Shacham } \\
\text { et al., } \\
2020 \text { (18) } \\
\end{array}$ & + & + & + & + & + & - & + & + & 7 & Low \\
\hline 16 & $\begin{array}{l}\text { Sun et al., } \\
2020 \text { (19) }\end{array}$ & \multicolumn{8}{|c|}{ Joanna Briggs Institute tool to assess qualitative studies used - 10 item tool(20): High quality evidence } & 9 & \\
\hline 17 & $\begin{array}{l}\text { Tan et al., } \\
2020(21)\end{array}$ & + & + & + & + & + & - & + & + & 7 & Low \\
\hline 18 & $\begin{array}{l}\text { Urooj et } \\
\text { al., } \\
2020 \text { (22) } \\
\end{array}$ & \multicolumn{9}{|c|}{ Mixed methods appraisal tool (MMAT) (23) S1-2 \& all 5 criteria addressed satisfactory: High quality evidence } & \\
\hline 19 & $\begin{array}{l}\text { S. Wang et } \\
\text { al., } \\
2020(24)\end{array}$ & + & + & + & + & + & - & + & + & 7 & Low \\
\hline 20 & $\begin{array}{l}\text { Wu et al., } \\
2020(25)\end{array}$ & + & - & + & + & + & - & + & + & 6 & Minor \\
\hline$\overline{21}$ & $\begin{array}{l}\text { Xiao et al., } \\
2020 \text { (26) }\end{array}$ & + & - & + & + & + & - & + & + & 6 & Minor \\
\hline 22 & $\begin{array}{l}\text { Xu et al., } \\
2020(24)\end{array}$ & \multicolumn{9}{|c|}{ Assessed with Critical Appraisal Skills Programme appraisal tool(27) } & Minor \\
\hline 23 & $\begin{array}{l}\text { Yin \& } \\
\text { Zeng, }\end{array}$ & \multicolumn{8}{|c|}{ Joanna Briggs Institute tool to assess qualitative studies used - 10 item tool (20): High quality evidence } & 10 & \\
\hline
\end{tabular}




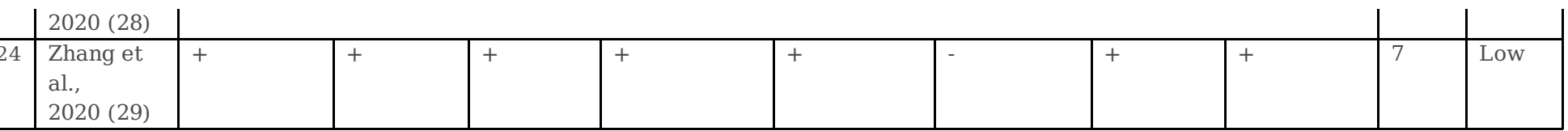

1. Moola S, Munn Z, Tufanaru C, Aromataris E, Sears K, Sfetcu R, et al. Chapter 7: Systematic reviews of etiology and risk. Joanna Briggs Institute Reviewer's Manual The Joanna Briggs Institute. 2017:2019-05.

2. Evidence Partners. Tool to Assess Risk of Bias. Contributed by the CLARITY Group at McMaster University: McMaster University; [Available from: https://www.evidencepartners.com/resources/methodological-resources/.

3. Ahmed MA, Jouhar R, Ahmed N, Adnan S, Aftab M, Zafar MS, et al. Fear and Practice Modifications among Dentists to Combat Novel Coronavirus Disease (COVID-19) Outbreak. International Journal of Environmental Research and Public Health. 2020;17(8):2821.

4. Balakumar C, Rait J, Montauban P, Zarsadias P, Iqbal S, Fernandes R. COVID-19: are frontline surgical staff ready for this? British Journal of Surgery. 2020.

5. Jüni P, Loke Y, Pigott T, Ramsay C, Regidor D, Rothstein H, et al. Risk of bias in non-randomized studies of interventions (ROBINS-I): detailed guidance. 2016.

6. Cai H, Tu B, Ma J, Chen L, Fu L, Jiang Y, et al. Psychological Impact and Coping Strategies of Frontline Medical Staff in Hunan Between January and March 2020 During the Outbreak of Coronavirus Disease 2019 (COVID-19) in Hubei, China. Medical Science Monitor: International Medical Journal of Experimental and Clinical Research. 2020;26:e924171-1.

7. Cai W, Lian B, Song X, Hou T, Deng G, Li H. A cross-sectional study on mental health among health care workers during the outbreak of Corona Virus Disease 2019. Asian Journal of Psychiatry. 2020;51:102111.

8. Cao J, Wei J, Zhu H, Duan Y, Geng W, Hong X, et al. A study of basic needs and psychological wellbeing of medical workers in the fever clinic of a tertiary general hospital in Beijing during the COVID-19 outbreak. Psychotherapy and Psychosomatics. 2020:1.

9. Chew NWS, Lee GKH, Tan BYQ, Jing M, Goh Y, Ngiam NJH, et al. A multinational, multicentre study on the psychological outcomes and associated physical symptoms amongst healthcare workers during COVID-19 outbreak. Brain, Behavior, and Immunity. 2020.

10. Chung JPY, Yeung WS. Staff Mental Health Self-Assessment During the COVID-19 Outbreak. East Asian Archives of Psychiatry: Official Journal of the Hong Kong College of Psychiatrists= Dong Ya Jing Shen ke xue zhi: Xianggang Jing Shen ke yi xue Yuan qi kan. 2020;30(1):34-.

11. Huang Y, Zhao N. Generalized anxiety disorder, depressive symptoms and sleep quality during COVID-19 epidemic in China: a web-based cross-sectional survey. medRxiv. 2020.

12. Kang L, Ma S, Chen M, Yang J, Wang Y, Li R, et al. Impact on mental health and perceptions of psychological care among medical and nursing staff in Wuhan during the 2019 novel coronavirus disease outbreak: A cross-sectional study. Brain, behavior, and immunity. 2020.

13. Lai J, Ma S, Wang Y, Cai Z, Hu J, Wei N, et al. Factors Associated With Mental Health Outcomes Among Health Care Workers Exposed to Coronavirus Disease 2019. JAMA Network Open. 2020;3(3):e203976-e.

14. Li Z, Ge J, Yang M, Feng J, Qiao M, Jiang R, et al. Vicarious traumatization in the general public, members, and non-members of medical teams aiding in COVID-19 control. Brain, behavior, and immunity. 2020.

15. Liang Y, Chen M, Zheng X, Liu J. Screening for Chinese medical staff mental health by SDS and SAS during the outbreak of COVID-19. Journal of Psychosomatic Research. 2020;133:110102.

16. Lu W, Wang H, Lin Y, Li L. Psychological status of medical workforce during the COVID-19 pandemic: A crosssectional study. Psychiatry Research. 2020:112936.

17. Mo Y, Deng L, Zhang L, Lang Q, Liao C, Wang N, et al. Work stress among Chinese nurses to support Wuhan for fighting against the COVID-19 epidemic. Journal of nursing management. 2020.

18. Shacham M, Hamama-Raz Y, Kolerman R, Mijiritsky O, Ben-Ezra M, Mijiritsky E. COVID-19 Factors and Psychological Factors Associated with Elevated Psychological Distress among Dentists and Dental Hygienists in Israel. International Journal of Environmental Research and Public Health. 2020;17(8):2900.

19. Sun N, Shi S, Jiao D, Song R, Ma L, Wang H, et al. A Qualitative Study on the Psychological Experience of Caregivers of COVID-19 Patients. American Journal of Infection Control. 2020.

20. Lockwood C, Munn Z, Porritt K. Qualitative research synthesis: methodological guidance for systematic reviewers utilizing meta-aggregation. International journal of evidence-based healthcare. 2015;13(3):179-87.

21. Tan BYQ, Chew NWS, Lee GKH, Jing M, Goh Y, Yeo LLL, et al. Psychological Impact of the COVID-19 Pandemic on Health Care Workers in Singapore. Annals of Internal Medicine. 2020. 
22. Urooj U, Ansari A, Siraj A, Khan S, Tariq H. Expectations, Fears and Perceptions of doctors during Covid-19 Pandemic. Pakistan Journal of Medical Sciences. 2020;36(COVID19-S4).

23. Hong QN, Fàbregues S, Bartlett G, Boardman F, Cargo M, Dagenais P, et al. The Mixed Methods Appraisal Tool (MMAT) version 2018 for information professionals and researchers. Education for Information. 2018;34(4):285-91.

24. Wang S, Xie L, Xu Y, Yu S, Yao B, Xiang D. Sleep disturbances among medical workers during the outbreak of COVID-2019. Occupational Medicine. 2020.

25. Wu Y, Wang J, Luo C, Hu S, Lin X, Anderson AE, et al. A comparison of burnout frequency among oncology physicians and nurses working on the front lines and usual wards during the COVID-19 epidemic in Wuhan, China. Journal of Pain and Symptom Management. 2020.

26. Xiao H, Zhang Y, Kong D, Li S, Yang N. The effects of social support on sleep quality of medical staff treating patients with coronavirus disease 2019 (COVID-19) in January and February 2020 in China. Medical science monitor: international medical journal of experimental and clinical research. 2020;26:e923549-1.

27. Critical Appraisal Skills Programme. Cohort Study Checklist: Critical Appraisal Skills Programme (CASP); [Available from: https://casp-uk.net/casp-tools-checklists/.

28. Yin X, Zeng L. A study on the psychological needs of nurses caring for patients with coronavirus disease 2019 from the perspective of the existence, relatedness, and growth theory. International Journal of Nursing Sciences. 2020. 29. Zhang W-r, Wang K, Yin L, Zhao W-f, Xue Q, Peng M, et al. Mental health and psychosocial problems of medical health workers during the COVID-19 epidemic in China. Psychotherapy and psychosomatics. 2020:1-9.

Table 3: Certainty of evidence for the risk factors associated with adverse mental health outcomes on health and care staff during the COVID-19 pandemic 


\begin{tabular}{|c|c|c|c|c|}
\hline $\begin{array}{c}\text { No of } \\
\text { studies }\end{array}$ & Design & $\begin{array}{c}\text { Risk } \\
\text { of } \\
\text { bias }\end{array}$ & Additional considerations & $\left.\begin{array}{c}\text { Certainty } \\
\text { (overall } \\
\text { score) }\end{array}\right]$ \\
\hline
\end{tabular}

Factor: Frontline staff/Close contact with COVID-19 patients (1-4)

\begin{tabular}{l|l|l|l|l}
\hline 4 & 2 & 2 & Inconsistency: Higher burnout reported in non-frontline staff (Cancer hospital, Wuhan). (5)
\end{tabular} Frontline nurses reported lower vicarious trauma scores. (6)

No difference between frontline and non-frontline staff reported (This finding was not statistically significant). (7)

Factor: Nurse $(2,8,9)$

\begin{tabular}{l|l|l|l|l}
\hline 3 & 2 & 2 & Inconsistency: Doctors were found to have more sleep disturbances than nurses (This finding was not
\end{tabular} statistically significant). (4)

Not all confounding factors were dealt with in the three studies reporting nurses to be at a higher risk for adverse psychological outcomes. No studies compared nurses to primary care or social staff.

Factor: Clinical healthcare workers $(3,10)$

\begin{tabular}{|l|l|l|l|l}
\hline 2 & 2 & 2 & Inconsistency in these findings. (11) \\
\hline
\end{tabular}

Factor: Heavy workload $(9,12,13)$

\begin{tabular}{|l|l|l|l|}
\hline 3 & 2 & 2 & No serious inconsistencies. \\
\hline
\end{tabular}

Factor: Lack of personal protective equipment (PPE) $(8,14-16)$

\begin{tabular}{|l|l|l|l|}
\hline 4 & 2 & 2 & No serious inconsistencies. \\
\hline
\end{tabular}

Factor: Point of outbreak $(13,17)$

\begin{tabular}{|l|l|l|l|l|l}
\hline 2 & 2 & 1 & Only two studies - one was limited to the sample of a surgical department where confounding factors were
\end{tabular} not dealt with and one was a qualitative study.

Factor: Rural location (10)

\begin{tabular}{|l|l|l|l|l}
\hline 1 & 2 & 0 & Only one study reported findings on effect of rurality.
\end{tabular}

Factor: Fear of infection $(9,14,18)$

\begin{tabular}{|l|l|l|l|l}
\hline 3 & 2 & 2 & No serious inconsistencies. \\
\hline
\end{tabular}

image

High

Factor: Concern about family $(8,9,13,15)$

\begin{tabular}{|l|l|l|l|l}
\hline 4 & 2 & 1 & This theme was predominantly raised in qualitative literature.
\end{tabular}

\section{Factor: Younger age $(7,8,19)$}

\begin{tabular}{l|l|l|l|l}
\hline 3 & 2 & 2 & Age was found to be a complex risk factor where the focus of anxiety depended on the age group
\end{tabular} assessed. (8)

Factor: Gender - Female (2, 10)

\begin{tabular}{l|l|l|l|l}
\hline 2 & 2 & 1 & Inconsistencies were found - for example: a large global survey of dentists found no differences based on
\end{tabular} gender. (18) Furthermore, confounding factors assessing gender in both included studies were not satisfactorily dealt with.

Factor: Organic illness $(10,20)$

\begin{tabular}{l|l|l|l|l}
\hline 2 & 2 & 1 & No serious inconsistencies.
\end{tabular}

Factor: Being an only child $(4,12)$

\begin{tabular}{|l|l|l|l|}
\hline 2 & 2 & 0 & No serious inconsistencies.
\end{tabular} Moderate

\begin{tabular}{l|l|l|l|l} 
& & & \\
\hline
\end{tabular}

1. Kang L, Ma S, Chen M, Yang J, Wang Y, Li R, et al. Impact on mental health and perceptions of psychological care among medical and nursing staff in Wuhan during the 2019 novel coronavirus disease outbreak: A cross-sectional study.

Brain, behavior, and immunity. 2020. 

workers exposed to coronavirus disease 2019. JAMA network open. 2020;3(3):e203976-e.

3. Lu W, Wang H, Lin Y, Li L. Psychological status of medical workforce during the COVID-19 pandemic: A crosssectional study. Psychiatry Research. 2020:112936.

4. Wang S, Xie L, Xu Y, Yu S, Yao B, Xiang D. Sleep disturbances among medical workers during the outbreak of COVID-2019. Occupational Medicine. 2020.

5. Wu Y, Wang J, Luo C, Hu S, Lin X, Anderson AE, et al. A comparison of burnout frequency among oncology physicians and nurses working on the front lines and usual wards during the COVID-19 epidemic in Wuhan, China. Journal of Pain and Symptom Management. 2020.

6. Li Z, Ge J, Yang M, Feng J, Qiao M, Jiang R, et al. Vicarious traumatization in the general public, members, and non-members of medical teams aiding in COVID-19 control. Brain, behavior, and immunity. 2020.

7. Liang Y, Chen M, Zheng X, Liu J. Screening for Chinese medical staff mental health by SDS and SAS during the outbreak of COVID-19. Journal of Psychosomatic Research. 2020;133:110102.

8. Cai H, Tu B, Ma J, Chen L, Fu L, Jiang Y, et al. Psychological Impact and Coping Strategies of Frontline Medical Staff in Hunan Between January and March 2020 During the Outbreak of Coronavirus Disease 2019 (COVID-19) in Hubei, China. Medical Science Monitor: International Medical Journal of Experimental and Clinical Research. 2020;26:e924171-1. 9. Cao J, Wei J, Zhu H, Duan Y, Geng W, Hong X, et al. A study of basic needs and psychological wellbeing of medical workers in the fever clinic of a tertiary general hospital in Beijing during the COVID-19 outbreak. Psychotherapy and Psychosomatics. 2020:1.

10. Zhang W-r, Wang K, Yin L, Zhao W-f, Xue Q, Peng M, et al. Mental health and psychosocial problems of medical health workers during the COVID-19 epidemic in China. Psychotherapy and psychosomatics. 2020:1-9.

11. Tan BYQ, Chew NWS, Lee GKH, Jing M, Goh Y, Yeo LLL, et al. Psychological Impact of the COVID-19 Pandemic on Health Care Workers in Singapore. Annals of Internal Medicine. 2020.

12. Mo Y, Deng L, Zhang L, Lang Q, Liao C, Wang N, et al. Work stress among Chinese nurses to support Wuhan for fighting against the COVID-19 epidemic. Journal of nursing management. 2020.

13. Sun N, Shi S, Jiao D, Song R, Ma L, Wang H, et al. A Qualitative Study on the Psychological Experience of Caregivers of COVID-19 Patients. American Journal of Infection Control. 2020.

14. Chung JPY, Yeung WS. Staff Mental Health Self-Assessment During the COVID-19 Outbreak. East Asian Archives of Psychiatry: Official Journal of the Hong Kong College of Psychiatrists= Dong Ya Jing Shen ke xue zhi: Xianggang Jing Shen ke yi xue Yuan qi kan. 2020;30(1):34-.

15. Urooj U, Ansari A, Siraj A, Khan S, Tariq H. Expectations, Fears and Perceptions of doctors during Covid-19 Pandemic. Pakistan Journal of Medical Sciences. 2020;36(COVID19-S4).

16. Yin X, Zeng L. A study on the psychological needs of nurses caring for patients with coronavirus disease 2019 from the perspective of the existence, relatedness, and growth theory. International Journal of Nursing Sciences. 2020. 17. Xu J, Xu Q-h, Wang C-m, Wang J. Psychological status of surgical staff during the COVID-19 outbreak. Psychiatry Research. 2020:112955.

18. Ahmed MA, Jouhar R, Ahmed N, Adnan S, Aftab M, Zafar MS, et al. Fear and Practice Modifications among Dentists to Combat Novel Coronavirus Disease (COVID-19) Outbreak. International Journal of Environmental Research and Public Health. 2020;17(8):2821.

19. Huang Y, Zhao N. Generalized anxiety disorder, depressive symptoms and sleep quality during COVID-19 epidemic in China: a web-based cross-sectional survey. medRxiv. 2020.

20. Shacham M, Hamama-Raz Y, Kolerman R, Mijiritsky O, Ben-Ezra M, Mijiritsky E. COVID-19 Factors and Psychological Factors Associated with Elevated Psychological Distress among Dentists and Dental Hygienists in Israel. International Journal of Environmental Research and Public Health. 2020;17(8):2900.

\footnotetext{
nage 1$]$ High $=$ This research provides a very good indication of the likely effect. The likelihood that the effect will be substantially different** is low.

ige 4 Moderate = This research provides a good indication of the likely effect. The likelihood that the effect will be substantially different** is moderate.

ige Low = This research provides some indication of the likely effect. However, the likelihood that it will be substantially different** is high.

$1 \oplus 000$ Very low $=$ This research does not provide a reliable indication of the likely effect. The likelihood that the effect will be substantially different** is very high.

** Substantially different $=$ a large enough difference that it might affect a decision
} 
Table 4: Certainty of evidence for the protective factors associated with mitigating adverse mental health outcomes on health and care staff during the COVID-19 pandemic.

\begin{tabular}{|c|c|c|c|c|}
\hline $\begin{array}{l}\text { No of } \\
\text { studies }\end{array}$ & Design & $\begin{array}{c}\text { Risk of } \\
\text { bias }\end{array}$ & Additional considerations & $\begin{array}{c}\text { Certainty } \\
\text { (overall } \\
\text { score) }{ }^{[1]}\end{array}$ \\
\hline \multicolumn{5}{|c|}{$\begin{array}{l}\text { Factor: Support (Community, social, team, government) } \\
(1-4)\end{array}$} \\
\hline 4 & 2 & 2 & No serious inconsistencies. & $\begin{array}{l}\text { image } \\
\text { High }\end{array}$ \\
\hline \multicolumn{5}{|c|}{ Factor: Adequate personal protective equipment (PPE) $(1,4)$} \\
\hline 2 & 2 & 0 & $\begin{array}{l}\text { Few studies assessed PPE directly as a protective factor. Many found it to be a risk factor when } \\
\text { inadequate. }\end{array}$ & $\begin{array}{l}\text { dimage } \\
\text { Low }\end{array}$ \\
\hline \multicolumn{5}{|c|}{ Factor: Being in a committed relationship (5) } \\
\hline 1 & 2 & 0 & Only one study assessed this factor. & $\begin{array}{l}\text { dimage } \\
\text { Very low }\end{array}$ \\
\hline \multicolumn{5}{|c|}{ Factor: Prior outbreak experience/COVID-19 Knowledge $(1,4,6,7)$} \\
\hline 4 & 2 & 1 & $\begin{array}{l}\text { No serious inconsistencies, but the data also included one low quality uncontrolled pre and post } \\
\text { exposure study, as well as a qualitative study. }\end{array}$ & $\begin{array}{l}\text { Mimage } \\
\text { Moderate }\end{array}$ \\
\hline \multicolumn{5}{|c|}{ Factor: Resilience $(3,5,7)$} \\
\hline 3 & 2 & 1 & Resilience was empirically measured with validated scores & $\begin{array}{l}\text { image } \\
\text { High }\end{array}$ \\
\hline \multicolumn{5}{|c|}{ Factor: Altruistic acts (2) } \\
\hline 1 & 2 & 1 & Only one qualitative study assessed this factor. & $\begin{array}{l}\text { Limage } \\
\text { Low }\end{array}$ \\
\hline \multicolumn{5}{|c|}{ Factor: Personal growth (2) } \\
\hline 1 & 2 & 1 & Only one qualitative study assessed this factor. & $\begin{array}{l}\text { Limage } \\
\text { Low }\end{array}$ \\
\hline \multicolumn{5}{|c|}{ Factor: Gratitude, Positive self-attitude $(1,2)$} \\
\hline 2 & 2 & 1 & This factor was not empirically measured. & $\begin{array}{l}\text { image } \\
\text { Low }\end{array}$ \\
\hline \multicolumn{5}{|c|}{ Factor: Sense of purpose (2) } \\
\hline 1 & 2 & 1 & Only one qualitative study assessed this factor. & $\begin{array}{l}\text { Limage } \\
\text { Low }\end{array}$ \\
\hline \multicolumn{5}{|c|}{ Factor: Safety of family (1) } \\
\hline 1 & 2 & 0 & Only one study assessed this factor. & $\begin{array}{l}\text { image } \\
\text { Very low }\end{array}$ \\
\hline
\end{tabular}

1. Cai H, Tu B, Ma J, Chen L, Fu L, Jiang Y, et al. Psychological Impact and Coping Strategies of Frontline Medical Staff in Hunan Between January and March 2020 During the Outbreak of Coronavirus Disease 2019 (COVID-19) in Hubei, China. Medical Science Monitor: International Medical Journal of Experimental and Clinical Research. 2020;26:e924171-1.

2. Sun N, Shi S, Jiao D, Song R, Ma L, Wang H, et al. A Qualitative Study on the Psychological Experience of Caregivers of COVID-19 Patients. American Journal of Infection Control. 2020.

3. Xiao H, Zhang Y, Kong D, Li S, Yang N. The effects of social support on sleep quality of medical staff treating patients with coronavirus disease 2019 (COVID-19) in January and February 2020 in China. Medical science monitor: international medical journal of experimental and clinical research. 2020;26:e923549-1.

4. Yin X, Zeng L. A study on the psychological needs of nurses caring for patients with coronavirus disease 2019 from the perspective of the existence, relatedness, and growth theory. International Journal of Nursing Sciences. 2020.

5. Shacham M, Hamama-Raz Y, Kolerman R, Mijiritsky O, Ben-Ezra M, Mijiritsky E. COVID-19 Factors and Psychological Factors Associated with Elevated Psychological Distress among Dentists and Dental Hygienists in Israel. International Journal of Environmental Research and Public Health. 2020;17(8):2900.

6. Balakumar C, Rait J, Montauban P, Zarsadias P, Iqbal S, Fernandes R. COVID-19: are frontline surgical staff ready for this? British Journal of Surgery. 2020.

7. Cai W, Lian B, Song X, Hou T, Deng G, Li H. A cross-sectional study on mental health among health care workers during the outbreak of Corona Virus Disease 2019. Asian Journal of Psychiatry. 2020;51:102111. 
[1]

nage 4 High $=$ This research provides a very good indication of the likely effect. The likelihood that the effect will be substantially different** is low.

age Moderate $=$ This research provides a good indication of the likely effect. The likelihood that the effect will be substantially different** is moderate.

age Low $=$ This research provides some indication of the likely effect. However, the likelihood that it will be substantially different** is high.

$1 \oplus \bigcirc 0 \bigcirc$ Very low = This research does not provide a reliable indication of the likely effect. The likelihood that the effect will be substantially different** is very high.

** Substantially different $=$ a large enough difference that it might affect a decision

\section{Figures}

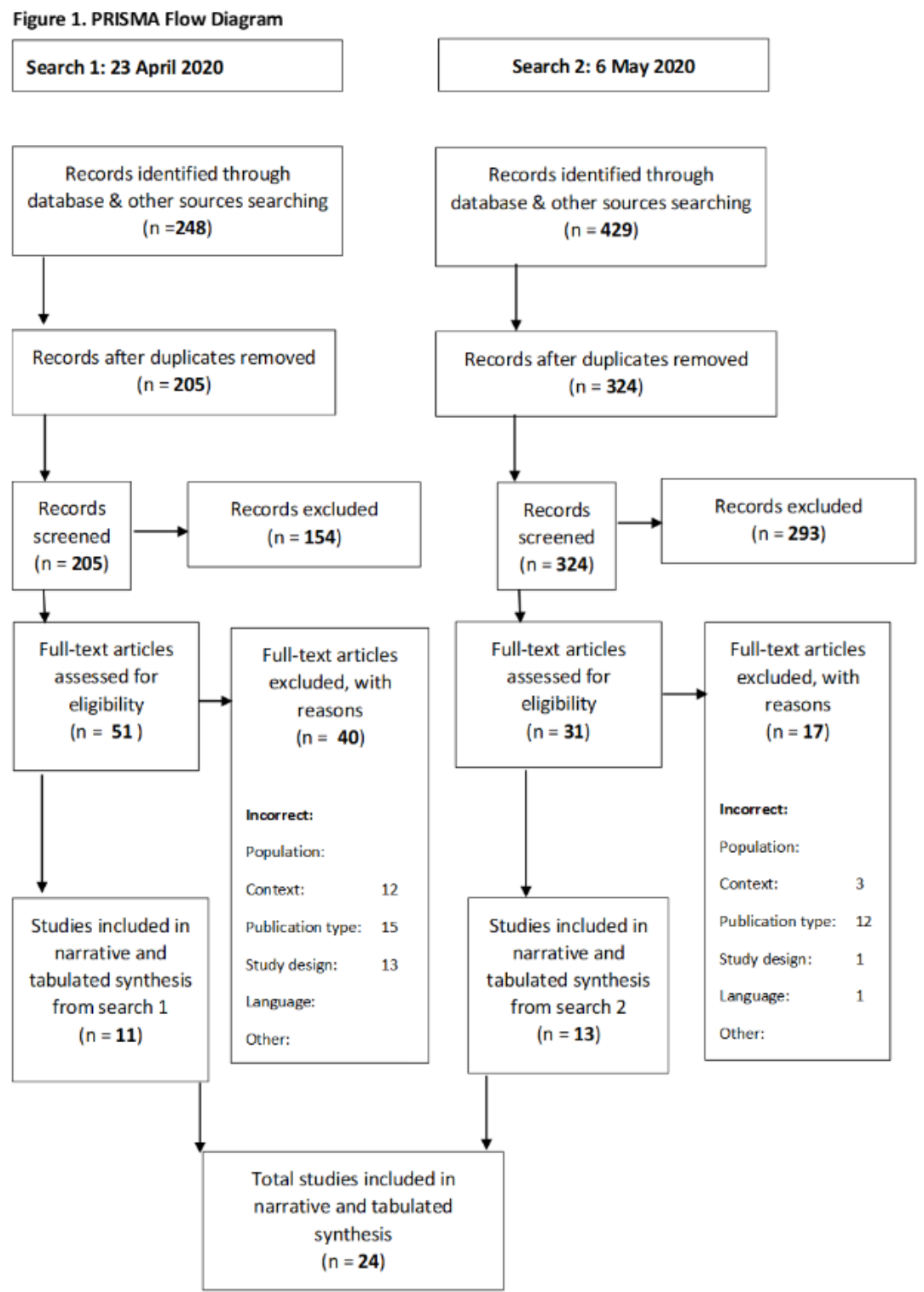

\section{Figure 1}

Prisma Flow Diagram

\section{Supplementary Files}

This is a list of supplementary files associated with this preprint. Click to download. 
- Appendix1SearchstrategyForFinaltogotoprint.docx

Page 28/28 